Article

\title{
Anthocyanins in Blueberries Grown in Hot Climate Exert Strong Antioxidant Activity and May Be Effective against Urinary Tract Bacteria
}

\author{
Ana B. Cerezo ${ }^{1}{ }^{(D}$, Giorgiana M. Cătunescu ${ }^{2, *}{ }^{\circledR}$, Mercedes Martínez-Pais González ${ }^{1}$, \\ Ruth Hornedo-Ortega ${ }^{3}$, Carmen R. Pop ${ }^{4}(1)$, Crina Claudia Rusu ${ }^{5}$, Flore Chirilă ${ }^{6}$, \\ Ancuța M. Rotar ${ }^{4}$ (D) M. Carmen Garcia-Parrilla ${ }^{1}$ (D) and Ana M. Troncoso ${ }^{1, * \mathbb{D}}$ \\ 1 Departamento de Nutrición y Bromatología, Toxicología y Medicina Legal, Facultad de Farmacia, \\ Universidad de Sevilla, C/Profesor García González 2, 41012 Sevilla, Spain; acerezo@us.es (A.B.C.); \\ marmargpub@gmail.com (M.M.-P.G.); mcparrilla@us.es (M.C.G.-P.) \\ 2 Department of Technical and Soil Sciences, Faculty of Agriculture, University of Agricultural Sciences and \\ Veterinary Medicine Cluj-Napoca, Calea Mănăștur 3-5, 400372 Cluj-Napoca, Romania \\ 3 Axe Molécules d'Intérêt Biologique (MIB), Unité de Recherche Enologie, EA4577, USC 1366 Institut \\ National de la Recherche Agronomique (INRA), Institut des Sciences de la Vigne et du Vin (ISVV), \\ Université de Bordeaux, 33882 Bordeaux, France; ruth.hornedo-ortega@u-bordeaux.fr \\ 4 Department of Food Science, Faculty of Food Science and Technology, University of Agricultural Sciences \\ and Veterinary Medicine Cluj-Napoca, Calea Mănăștur 3-5, 400372 Cluj-Napoca, Romania; \\ carmen-rodica.pop@usamvcluj.ro (C.R.P.); anca.rotar@usamvcluj.ro (A.M.R.) \\ 5 Department of Nephrology, University of Medicine and Pharmacy “Iuliu Hatieganu”, Victor Babeş 8, \\ 400012 Cluj-Napoca, Romania; claudia.rusu@umfcluj.ro \\ 6 Department of Clinical and Paraclinical Sciences, Faculty of Veterinary Medicine, University of Agricultural \\ Sciences and Veterinary Medicine Cluj-Napoca, Calea Mănăștur 3-5, 400372 Cluj-Napoca, Romania; \\ flore.chirila@usamvcluj.ro \\ * Correspondence: giorgiana.catunescu@usamvcluj.ro (G.M.C.); amtroncoso@us.es (A.M.T.)
}

Received: 30 April 2020; Accepted: 1 June 2020; Published: 2 June 2020

\begin{abstract}
Anthocyanins are extensively studied for their health-related properties, including antibacterial activity against urinary tract infections (UTI). Among common fruits, blueberries, with their remarkable antioxidant capacity, are one of the richest sources. Anthocyanin-rich extracts were obtained from four varieties: Snowchaser, Star, Stella Blue and Cristina Blue, grown in the hot climate of Southern Spain. Their total anthocyanins contents (TAC) were determined spectrophotometrically, and the anthocyanin profile by ultra high performance liquid chromatography-tandem mass spectrometer (UHPLC-MS/MS). Their antioxidant activity was assessed by oxygen radical absorbance capacity (ORAC) assay, while antibacterial activity against strains isolated from UTI patients was assessed in vitro, helping to select the varieties with the highest bioactive potential. Star showed the highest TAC and antioxidant activity $(1663 \pm 159 \mathrm{mg}$ of cyanidin-3-O-glucoside (cy-3-O-glu) equivalents/100 g fresh weight (FW), $6345 \pm 601 \mu \mathrm{mol}$ Trolox equivalents (TE)/100 g FW, respectively), followed by Cristina Blue, Stella Blue and Snowchaser. As far as we know, this is the first time that cyanidin-3-rutinoside has been identified in blueberries. The extracts inhibited all the tested strains, MICs ranging from $0.4 \mathrm{mg} / \mathrm{mL}$ (for Stella Blue extract against UTI P. aeruginosa) to $9.5 \mathrm{mg} / \mathrm{mL}$ (for all extracts against UTI K. pneumoniae ssp. pneumoniae). This is the first study that assessed in vitro the antibacterial activity of blueberries against Klebsiella pneumoniae, Providencia stuartii and Micrococcus spp. strains isolated from UTI.
\end{abstract}

Keywords: antibacterial activity; Escherichia coli; Klebsiella pneumoniae; Pseudomonas aeruginosa; Providencia stuartii; Micrococcus; cyanidin-3-rutinoside; ORAC; UHPLC-MS/MS Orbitrap 


\section{Introduction}

Berries contain high amounts of polyphenols, including flavonoids, and are widely consumed globally. Due to their healthful properties in a broad number of biological functions [1], anthocyanin pigments, considered to be the most abundant flavonoids in berries, have been extensively studied. There are currently more than 600 different anthocyanins described in the plant kingdom [2-7]. Their reported healthy effects are mainly related to their antioxidant and anti-inflammatory activity in the prevention of some metabolic disorders [8]. Recent studies have shown that an increase in anthocyanin dietary intake (from 3 to $24 \mathrm{mg} /$ day) is significantly associated with a 12-32\% [9-11] reduction in the risk of coronary heart disease. Cassidy et al. [9] have shown that, for every $15 \mathrm{mg}$ increase in anthocyanin consumption, the relative risk of myocardial infarction decreases by $17 \%$. Notably, berries are the main food source of anthocyanins in Europe (11\%) [12]. The consumption of three servings per week (approximately $225 \mathrm{~g}$ ) of strawberries or blueberries has been associated with a significant decrease in the risk of myocardial infarction [9] and overall cardiovascular risk [13]. Additionally, berries of the Vaccinium genus have shown potential for use in urinary tract infections (UTI). Anthocyanins extracted from cranberries are widely known as an adjuvant in preventing or treating UTI [14-18]. Blueberries (Vaccinium corymbosum L.) present a significantly higher concentration (32-407 mg/100 g fresh weight (FW)) and diversity of anthocyanins (10-23) compared to other berry fruits, such as strawberries, grapes and raspberries (27-48 mg/100 g FW; seven to seventeen different compounds) [19-27]. Among common fruits, blueberries, therefore, are one of the richest sources of anthocyanins, making them extremely interesting fruits in terms of bioactive potential, with a remarkable antioxidant capacity [28,29].

It is not surprising that blueberry cultivation is currently booming. Southern Spain is the leading blueberry producer in Europe and fourth in the world. Blueberry production is rapidly increasing because of its excellent productivity, adaptability to different environments and pest resistance [30]. It is worth noting that both the anthocyanin profile and their respective concentrations vary significantly among the different varieties, growing areas and also intra- and inter-harvests [20,31-34]. Most of the varieties grown in Andalusia, a region located in Southern Spain, Cielo, Katiblue, Rockinoee, Star, Stella Blue, Terrapin, Emerald, Jewel, Snowchaser, Rocío, etc., have been adapted to the warm climate of southern Europe, taking advantage of an earlier January-June maturing season than the rest of Europe.

To date, most studies carried out on the anthocyanin profile of blueberries have focused on varieties grown in countries such as the USA, Chile, Germany, Italy or Canada (V. corymbosum var. Nui, Darrow, Reka, Puru, Bluegold, Berkeley, Legacy, Sampson, Elliott, Pamlico) [20,22,25,31,35-37]. The genotype (variety) has a significant impact on the concentration and anthocyanin profile of blueberries, determining not only their overall concentration but also the major anthocyanins [20,21,31-34,38]. Those anthocyanins most characteristic of blueberries are glycosides (glucosides, galactosides and arabinosides) and, in a smaller proportion, acetylated derivatives of cyanidin, delphinidin, malvidin, peonidin and petunidin. The varieties that have shown the highest concentration of total anthocyanins were Elliott and Pamlico (407 and $384 \mathrm{mg} / 100 \mathrm{~g}$ FW, respectively) [22,38].

Furthermore, it has been shown that the cultivation area also plays a key role in both the anthocyanin profile and total concentration. For the Legacy variety, total anthocyanins are significantly higher when cultivated in the warm climate of North Carolina (USA) (261 mg/100 g FW), as compared with the continental climate of North-East Romania (189 mg/100 g FW) [31,38]. Blueberry cultivation enables fruits to be collected as many as eight times from the same bush per season. Furthermore, the concentration and profile also vary significantly within and between harvests, due to changes in environmental conditions such as temperature and rainfall. Therefore, anthocyanin concentrations are higher in fruits collected in hotter $\left(30-33^{\circ} \mathrm{C}\right)$ months and years with a lower rainfall $(7-47 \mathrm{~mm})$ [20]. In conclusion, a warm climate and high temperatures yield fruits with a higher anthocyanin concentration. 
The United States is the world's largest producer of blueberries [39]. More recently, Andalusia, Spain, has become an important producer and is at present the largest producer in Europe (51.569 tonnes in 2019) [40]. Nevertheless, only one study has evaluated the anthocyanin profile of three different Andalusian varieties: Rocío and two other experimental varieties (V2 and V3). They contained glycosides and acetylated derivatives of delphinidin, petunidin, cyanidin and malvidin (not peonidin), with malvidin 3-hexoside being the major anthocyanin [41]. The authors also demonstrated that the bush's genotype has a significant effect on the anthocyanin profile, and that their concentrations vary between harvests. It is worth noting that some varieties currently under cultivation in Andalusia, such as Snowchaser, Emerald and Jewel, accumulated total anthocyanins ranging from 63-101 mg/100 g in other blueberry-producing regions [42,43].

Many studies have reported the antibacterial activity of anthocyanins extracted from blueberries against various Gram-positive (Listeria monocytogenes, Staphylococcus aureus and Clostridium perfringens) and Gram-negative (Salmonella enterica, E. coli and Campylobacter spp.) foodborne pathogens [44-54]. However, many of these studies were performed with complex extracts, obtained using different methods. It is not entirely clear which particular compounds are responsible for the antibacterial activity observed [55].

Similar to cranberries, blueberries are rich in anthocyanins, but their efficacy as an adjuvant in preventing or treating UTI is still in doubt and unclear $[18,56]$. Only a few in vitro studies have tested their effect against uropathogenic E. coli strains isolated from the urine of human patients diagnosed with UTI, and only one against Pseudomonas aeruginosa $[50,57,58]$. Although these findings appear promising, researchers have yet to find the array of susceptible pathogens. It is, therefore, currently of interest to evaluate the antibacterial activity of blueberry anthocyanins, not only against foodborne pathogens, but also against bacteria strains associated with UTI infections. Moreover, similar promising results were obtained in the case of other berries different to cranberries such as Aronia melanocarpa [59].

Anthocyanins extracts might be attractive adjuvants and/or alternatives to synthetic antibiotics, because they contain dynamic combinations of bioactive phytochemicals that might combat resistance on various complementary levels [47]. Current results show that complex mixtures of blueberry extracts show a better antibacterial efficacy against Salmonella and Campylobacter compared to individual compounds [60], most likely because of the synergy among the phytochemicals [60-62]. Thus, investigating complex anthocyanin mixtures instead of the purified compounds would appear justifiable.

Since substantial differences have been found in terms of anthocyanins concentration and diversity in blueberries grown in countries with different climatic conditions, their bioactive properties may thus vary, due to changes in their anthocyanin profiles. In order, therefore, to select those varieties that show an optimum anthocyanin profile and potent bioactive properties, identifying and quantifying the anthocyanins of blueberries grown in Andalusia is of great importance.

The aim of the present study is to evaluate the total anthocyanins content (TAC) and the anthocyanins profile of four blueberry varieties: Snowchaser, Star, Stella Blue and Cristina Blue, which are grown in Andalusia, in order to determine which variety presents the highest TAC, and to discriminate them based on their anthocyanins composition. Simultaneously, we intend to assess the antioxidant activity and the in vitro antibacterial activity of the extracted anthocyanins against standard pathogenic strains and bacteria isolated from patients suffering from UTI. This would enable those varieties with the greatest bioactive potential to be selected.

To the best of our knowledge, not only is this the first attempt to evaluate the TAC and anthocyanins profile of Snowchaser, Star, Stella Blue and Cristina Blue grown in Andalusia, but it is also the first evaluation of the in vitro effect of blueberry anthocyanins on potential uropathogenic bacteria strains, such as: Klebsiella pneumoniae, Providencia stuartii and Micrococcus spp. 


\section{Materials and Methods}

\subsection{Reagents}

Amberlite XAD7HP, AAPH (2,2'-diazo-bis-amidinepropane-dihydrochloride) and Trolox (6-hydroxy-2,5,7,8-tetramethylchroman-2-carboxylic) were purchased from Sigma (Munich, Germany). Fluorescein was provided by Fluka. Methanol for liquid chromatography and acetic acid 99.8\% were purchased from Merck (Munich, Germany) and VWR CHEMICALS (Radnor, PA, United States), respectively. Malvidin-3-glucoside, cyanidin-3-glucoside, cyanidin-3-galactoside, peonidin-3-glucoside and delphinidin-3-glucoside were purchased from Extrasynthese (Genay, France).

\subsection{Samples}

Four different varieties of highbush blueberry (Vaccinum corymbosum) were analysed: Snowchaser, Star, Stella Blue and Cristina Blue. They were all grown in the hot climate of Huelva, Southern Spain, in the towns of Palos de la Frontera and Almonte. Blueberries at commercial ripening were sampled from February to March 2019, depending on when the harvest of each variety commenced.

\subsection{Extraction of Anthocyanin Fraction}

Once collected, the whole blueberries (200 g FW) were immediately frozen at $-80{ }^{\circ} \mathrm{C}$ for at least $24 \mathrm{~h}$ and subsequently freeze-dried. The resultant dry samples were independently mixed with $200 \mathrm{~mL}$ of acidified methanol (0.5\% acetic acid) using a homogeniser [20,21,38], before being centrifuged at $3452 \mathrm{~g}$ for $10 \mathrm{~min}$ at $20^{\circ} \mathrm{C}$, and the supernatant fraction then being collected. Re-extraction was performed until the pellet was colourless. The supernatant of each variety was filtered, concentrated under vacuum at $35{ }^{\circ} \mathrm{C}$ to remove methanol, and then diluted 1:1 with water. The purification of the anthocyanins fraction of each variety was performed as previously described in the literature [6,20,21,23,63], using an Amberlite XAD-7 column $(30 \times 1.5 \mathrm{~cm})$ previously activated with methanol, and then $300 \mathrm{~mL}$ of water. Samples were loaded onto the column and cleaned with $450 \mathrm{~mL}$ of water, in order to remove free sugars, pectin, and organic acid, among other polar compounds. The anthocyanin fraction was eluted with methanol/acetic acid solution (19:1, v/v) at 1 drop/s flow, concentrated under vacuum, frozen at $-80{ }^{\circ} \mathrm{C}$ and freeze-dried to obtain the anthocyanin extract (Table 1).

Table 1. Ratio of anthocyanin extract obtained from each blueberry variety.

\begin{tabular}{cc}
\hline Variety & $\begin{array}{c}\text { Ratio } \\
\text { (mg Anthocyanin Extract/100 g FW) }\end{array}$ \\
\hline Star & 704.9 \\
Snowchaser & 253.8 \\
Cristina Blue & 431.7 \\
Stella Blue & 439.1 \\
\hline
\end{tabular}

\subsection{Total Anthocyanin Content (TAC)}

Total monomeric anthocyanin content was determined by the $\mathrm{pH}$ differential method [64]. Solutions used were potassium chloride buffer $(\mathrm{KCl})$ at $\mathrm{pH}=1.0(0.025 \mathrm{M})$ and sodium acetate buffer $\left(\mathrm{C}_{2} \mathrm{H}_{3} \mathrm{NaO}_{2}\right)$ at $\mathrm{pH}=4.5(0.8 \mathrm{M})$. The anthocyanin extract of each variety was prepared twice: once with potassium chloride buffer $(\mathrm{pH} 1.0)$ and then with sodium acetate buffer ( $\mathrm{pH} 4.5)$. They were settled for 15 min before their absorbances were measured in the spectrophotometer. Absorbance (A) was measured at $500 \mathrm{~nm}$ and $700 \mathrm{~nm}$ for each sample in both buffers. Samples were analysed in triplicate (duplicates of three different days). The following formulae were applied to estimate the total anthocyanin content:

$$
\mathrm{A}=\left(\mathrm{A}_{500}-\mathrm{A}_{700}\right) \mathrm{pH} 1.0-\left(\mathrm{A}_{500}-\mathrm{A}_{700}\right) \mathrm{pH} 4.5
$$




$$
\mathrm{TAC}(\mathrm{mg} / 100 \mathrm{~g} \mathrm{FW})=(\mathrm{A} \times \mathrm{MW} \times 1000) /(\varepsilon \times 1)
$$

where MW is the molecular weight of cyanidin-3-O-glucoside (cy-3-O-glu) (MW $=449.2 \mathrm{~g} / \mathrm{moL}$ ), and $\varepsilon$ its molar absorptivity $\left(26,900 \mathrm{~L} \mathrm{~cm}^{-1} \mathrm{~mol}^{-1}\right)$. Total anthocyanin content (TAC) is expressed as mg cy-3-O-gluc/100 g of FW.

\subsection{Oxygen Radical Absorbance Capacity (ORAC)}

The antioxidant capacity was measured by oxygen radical absorbance capacity (ORAC), as described in Ou et al. [65]. A total of $50 \mu \mathrm{L}$ of the extracts or Trolox $(0.5-15 \mu \mathrm{M})$ were mixed with $100 \mu \mathrm{L}$ of fluorescein $(90 \mathrm{nM})$ and $50 \mu \mathrm{L}$ AAPH $(15 \mathrm{nM})$ in black 96-well plate. Phosphate buffer and fluorescein controls were also included. A total of $50 \mu \mathrm{L}$ of phosphate buffer, $100 \mu \mathrm{L}$ of fluorescein and $50 \mu \mathrm{L}$ of AAPH were used as blank. The analysis was performed at $37^{\circ} \mathrm{C}$. Fluorescence at excitation and emission wavelengths of $485 \mathrm{~nm}$ and $528 \mathrm{~nm}$, respectively, was recorded every $5 \mathrm{~min}$ for $60 \mathrm{~min}$ using a multi-detection microplate reader (Synergy HT, Biotek, Winooski, VT, United States). Samples were analysed in triplicate (triplicates on three different days).

The ORAC values were calculated using the differences between the blank and the sample areas under the fluorescein decay curve. Results are expressed as $\mu \mathrm{mol}$ Trolox equivalents (TE)/100 g of FW.

\subsection{Identification of Anthocyanins: UHPLC-MS/MS Orbitrap}

Identification of the blueberries' anthocyanins was performed by a UHPLC-MS/MS (ultra-highperformance liquid chromatography) coupled to a hybrid quadrupole-orbitrap mass spectrometry system (Qexactive, Thermo Fisher, Waltham, Massachusetts, United States) with electrospray ionisation (HESI-II). The analytical conditions were previously described by Hornedo-Ortega et al. [63]. Separation was carried out using a reverse-phase ZORBAX SB-C18 rapid resolution HD $(2.1 \times 100 \mathrm{~mm}, 1.8 \mu \mathrm{m})$ column (Agilent, Santa Clara, CA, United States). The injected volume was $1 \mu \mathrm{L}$ (extract dissolved in mobile phase A) and the flow was $0.4 \mathrm{~mL} / \mathrm{min}$. The mobile phase (A: water/formic acid 95:5, v/v; B: acetonitrile/formic acid 95:5, v/v) gradient was as follows: $0-2 \mathrm{~min} 5 \% \mathrm{~B}, 2-12 \mathrm{~min}$ from $5 \%$ to $100 \% \mathrm{~B}, 12-13 \mathrm{~min}$ from 100 to $5 \% \mathrm{~B}$, and $5 \%$ B for $15 \mathrm{~min}$. Analyses were carried out using full MS scan from 100-1500 m/z, and high collision energy dissociation (HCD). The MS/MS parameters were as follows: positive ionisation mode, resolution of 35000, $20 \mathrm{eV}$ per cell, $3.5 \mathrm{kV}$ of voltage, $50 \mathrm{~V}$ in the lens of the channel, capillary temperature $320^{\circ} \mathrm{C}, 12.5$ and 50 (arbitrary units) flux of the auxiliary gas $\left(\mathrm{N}_{2}\right)$ and gas boosting. Xcalibur Software (version 3.0.63, Waltham, Massachusetts, United States) was used to analyse the data. Identification was performed according to their accurate molecular mass, molecular formula, calculated mass, characteristic fragmentation and retention time. The following anthocyanin standards were used for identification purposes: malvidin-3-glucoside, cyanidin-3-glucoside, cyanidin-3-galactoside, peonidin-3-glucoside and delphinidin-3-glucoside.

\subsection{Bacterial Strains}

\subsubsection{Standard Strains}

Standard strains, Escherichia coli ATCC (American Type Culture Collection) 25922, Salmonella Enteritidis ATCC 13076, Listeria monocytogenes ATCC 19114 were tested as controls. They were grown in a test tube containing $10 \mathrm{~mL}$ sterile nutrient broth (Oxoid Ltd., Basingstoke, Hampshire, England) at $37^{\circ} \mathrm{C}$ for $24 \mathrm{~h}$. A loopful of inoculum was transferred onto selective media: TBX agar for E. coli, XLD agar for Salmonella Enteritidis (Oxoid Ltd., Basingstoke, Hampshire, England) and Palcam agar base supplemented with Listeria Palcam antimicrobic supplement (Oxoid Ltd., Basingstoke, Hampshire, England) for Listeria monocytogenes. Plates were incubated for $24 \mathrm{~h}$ at $37^{\circ} \mathrm{C}$. Bacterial morphology was confirmed by optical microscopy. 


\subsubsection{Uropathogenic Bacteria Isolated from UTI Patients}

Urine was collected from 6 human patients who had given their written consent, in accordance with the ethics protocol of the collecting hospital, the County Emergency Hospital Cluj-Napoca, Romania (SCJU). The inclusion criteria were age above 18 years and the presence of clear clinical signs of UTI: hypogastric pain or/and dysuria or/and pollakiuria or/and disturbed urine or/and renal colic [66]. The exclusion criteria were antibiotic treatments $48 \mathrm{~h}$ previous to sampling and absence of leucocytes and/or of nitrites on dipstick analysis [66]. The selected patients were instructed on how to collect the samples. Their clean catch mid-stream urine samples were collected using the provided wide mouth 50 mL sterile universal containers, according to the current widely accepted Danish recommendations [66]. The secure-closed containers, each containing at least $20 \mathrm{~mL}$ of urine, were sent for microbiology testing. Each urine specimen was cultured within $30 \mathrm{~min}$ of sample collection as follows: $50 \mu \mathrm{L}$ of urine was vortexed and then inoculated on glucose agar plates using a sterile loop and incubated in aerobic conditions at $37^{\circ} \mathrm{C}$ for $18-24 \mathrm{~h}$. For the plates where bacterial growth was observed, the bacteria were identified by the conventional morphological and standard culture-based methods and by biochemical characteristics using the Vitek 2 system $[67,68]$. The colonies' genus and species were identified by microscopic examination of the Gram-stained smear to assess the morphology of the cells' shape, size and the presence of pigments. The strains were also biochemically characterised using the Vitek 2 system, according to the manufacturer's instructions. In the end, 6 bacteria of UTI importance were isolated and identified, 4 Gram-negative: Escherichia coli $\beta$-Haemolytic, Providencia stuartii, Klebsiella pneumoniae ssp. pneumoniae, Pseudomonas aeruginosa and 1 Gram-positive Micrococcus spp.

\subsubsection{Preparation of Bacterial Strains}

Several colonies of standard and UTI bacteria cultivated on Mueller-Hinton agar (Oxoid Ltd., Basingstoke, Hampshire, England) were transferred into sterile saline solution (8.5 g/L) and adjusted to match the turbidity of McFarland 0.5 standard $\left(1.5 \times 10^{8} \mathrm{CFU} / \mathrm{mL}\right)$. Then, a bacterial suspension of $1.5 \times 10^{6} \mathrm{CFU} / \mathrm{mL}$ was prepared for addition to each microplate well.

\subsection{Determination of the Minimum Inhibitory Concentration (MIC)}

The MIC was determined using the resazurin microtiter plate-based antibacterial assay [69,70]. Fresh stock methanolic solutions of the blueberry anthocyanin-rich extracts were prepared each experimental day at concentration of $20 \mathrm{mg} / \mathrm{mL}$ of $70 \%$ methanol. One hundred microliters of sterile nutrient broth (Oxoid Ltd., Basingstoke, Hampshire, England) were added in the wells of a 96-well microplate. Then $100 \mu \mathrm{L}$ of stock solutions were added in the first wells of each row and serial 11-fold dilutions were performed in the subsequent wells of each row by transferring $100 \mu \mathrm{L}$ from well to well. The surplus $100 \mu \mathrm{L}$ in the last well of the row was discarded. Then, $10 \mu \mathrm{L}$ of inoculum $\left(1.5 \times 10^{6} \mathrm{CFU} / \mathrm{mL}\right)$ was added to all wells. The actual tested concentrations of the methanolic solutions of the anthocyanin-rich extracts were: $9.520 \mathrm{mg} / \mathrm{mL} ; 4.530 \mathrm{mg} / \mathrm{mL} ; 2.182 \mathrm{mg} / \mathrm{mL} ; 1.038 \mathrm{mg} / \mathrm{mL}$; $0.494 \mathrm{mg} / \mathrm{mL} ; 0.235 \mathrm{mg} / \mathrm{mL} ; 0.112 \mathrm{mg} / \mathrm{mL} ; 0.053 \mathrm{mg} / \mathrm{mL} ; 0.025 \mathrm{mg} / \mathrm{mL} ; 0.012 \mathrm{mg} / \mathrm{mL} ; 0.006 \mathrm{mg} / \mathrm{mL}$; $0.003 \mathrm{mg} / \mathrm{mL}$. Gentamicin $(0.04 \mathrm{mg} / \mathrm{mL}$ in saline solution) was the positive control, and $70 \%$ methanol was the negative control.

The microplates were incubated for $20-22 \mathrm{~h}$ at $37^{\circ} \mathrm{C}$ and, then $20 \mu \mathrm{L}$ of $0.2 \mathrm{mg} / \mathrm{mL}$ resazurin aqueous solution was added to all wells. The microplates were incubated for another $2 \mathrm{~h}$ at $37^{\circ} \mathrm{C}$. After this period of incubation, resazurin (a blue non-fluorescent dye) was oxidised to resorufin (fluorescent pink) wherever the wells contained viable bacterial cells. The concentration in last blue well on each row was considered the lowest that completely inhibited bacterial growth, thus the MIC. Three replicates were performed for each bacterium and each stock methanolic solutions. 


\subsection{Determination of the Minimum Bactericidal Concentration (MBC)}

MBC was determined by plating $10 \mu \mathrm{L}$ from the last 4 blue wells on each row (the 4 lowest concentrations that showed inhibition of bacterial growth) in the MIC testing on Mueller-Hinton solid culture medium (Oxoid Ltd., Basingstoke, Hampshire, England) [69]. The plates were incubated for $24 \mathrm{~h}$ at $37^{\circ} \mathrm{C}$. The lowest concentration that prevented bacteria growth (no colonies on the plate) was considered to be the $\mathrm{MBC}$. Three different biological replicates were performed for each plate and all experiments were performed in duplicate.

\subsection{Statistical Analysis}

The results were statistically analysed using Graphpad Prism software (GraphPad Software, Inc., San Diego, CA, USA) and XLSTAT software (Addinsoft, New York, New York, USA, XLSTAT 2020.1.3.65245) [71]. Student's t-test was used to analyse the obtained data from TAC and ORAC, with differences at $p<0.01$ considered significant. A one-way ANOVA $(p<0.05)$ within samples was used to compare the 4 blueberry varieties and their antibacterial effect against the tested bacteria. Fisher pairwise comparisons (LSD, $p<0.05$ ) were made whenever ANOVA indicated a significant difference. Pearson correlational analyses were performed to examine the TAC/ORAC relationship and antibacterial activity. Whenever a correlation was confirmed, a linear regression was performed with a 95\% confidence interval, a tolerance of 0.0001 and a model selection based on best model by $R^{2}$, to establish and quantify the effect of TAC and antioxidant activity (ORAC) on the antibacterial activity.

\section{Results and Discussion}

\subsection{Total Anthocyanins Content (TAC)}

Figure 1 shows that Star was the variety with the significant highest anthocyanin concentration (1663 $\pm 159 \mathrm{mg}$ cy-3-O-glu/100 g FW), followed by Cristina Blue (733.4 $\pm 30.9 \mathrm{mg}$ cy-3-O-glu/100 g FW), Stella Blue (682.6 $\pm 14.7 \mathrm{mg}$ cy-3-O-glu/100 g FW) and Snowchaser (384.8 $\pm 4.4 \mathrm{mg}$ cy-3-O-glu/100 g FW). The TAC of Snowchaser has previously been reported for fruits cultivated in the South of Brazil (62.36 mg cy-3-O-glu/100g FW) [42]. Despite the fact that both the South of Brazil and Spain share a hot climate, total Snowchaser anthocyanin was six times higher when cultivated in Spain. TAC values ranging 31.54-406.9 mg cy-3-O-glu/100 g FW have been reported for Agropaine, Arlen, Berkley, Blomidom, Bluecrop, Bluegold, Bluejay, Brigitta, Chipava, Darrow, Duke, Elliott, Hannah's Choice, Legacy, Lenoir, Nelson, North Country, Northblue, Northland, Nui, O'Neal, Pamlico, Sampson, Toro, Jersey, Croatan, Rancocas and Rubel varieties [22,25,31,36,38,72,73]. All of the above were grown in the USA, Romania, Slovenia, Korea and Chile, but not in Spain. Our results show that Star, Cristina Blue and Stella Blue varieties cultivated in Southern Spain exhibited higher TAC values than previously published. Interestingly, Star presents four times higher anthocyanin content than the richest variety in anthocyanins (Elliott) so far reported [22].

Our results show that Star, Cristina Blue, Stella Blue and Snowchaser blueberries contain higher anthocyanin concentrations compared with other edible fruits, such as strawberry $(21.2-41.7 \mathrm{mg}$ cy-3-O-glu/100g FW), plum (56.0-124.5 mg/100g FW), red grape (48.0-121.1 mg/100g FW), cherry (32.0-122.0 mg/100g FW), blackberry (100.0-300.5 mg/100g FW) and cranberry (140 mg/100g FW). However, their anthocyanin content is in the range of blackcurrant (476 mg/100g FW), elderberry (1375 mg/100g FW), chokeberry (1480 mg/100g FW) and black raspberry (687 mg/100g FW) [19,28].

Considering a serving size of $150 \mathrm{~g}$ of blueberry, the anthocyanin content of the blueberry varieties under study would range from 577.2 to $2494.5 \mathrm{mg}$ cy-3-O-glu/serving. 


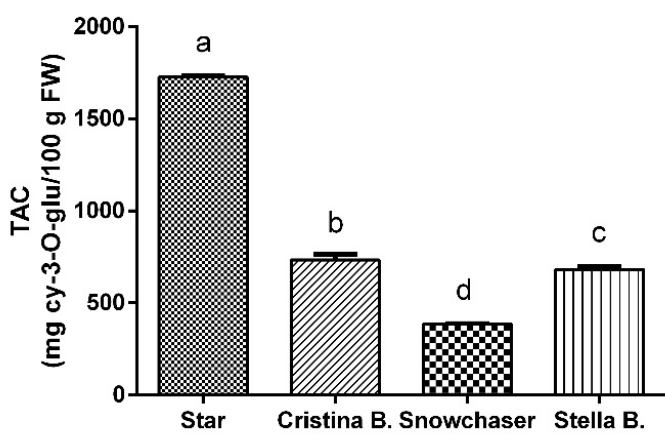

(a)

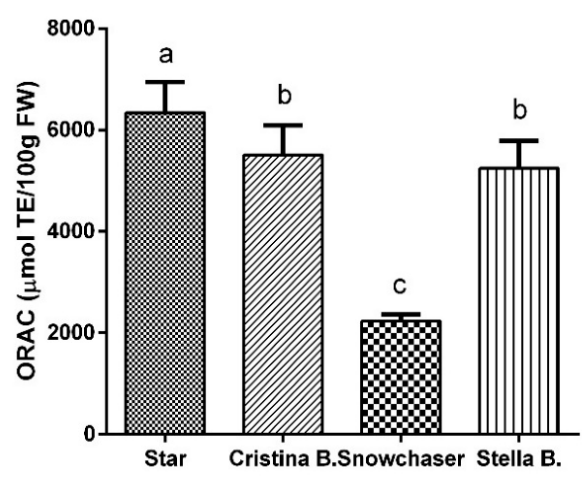

(b)

Figure 1. Total anthocyanin concentration (a) and antioxidant activity (b) of the different blueberry varieties. Total anthocyanin content (TAC) results are expressed as mg of cy-3-O-gluc/100 $\mathrm{g}$ fresh weight (FW) and oxygen radical absorbance capacity (ORAC) values as $\mu \mathrm{mol}$ of Trolox equivalents/100 $\mathrm{g}$ FW. Values represent mean $\pm \mathrm{SD}$ of three replicates $(n=3)$. Different letters mean significant differences between the four varieties at a level $p<0.01$ (Student's $t$-test).

\subsection{Antioxidant Capacity: ORAC Assay}

The antioxidant capacity of the analysed blueberry anthocyanin-rich extracts is presented in Figure 1, expressed as $\mu \mathrm{mol} \mathrm{TE} / 100 \mathrm{~g}$ FW. Antioxidant activity followed similar trend to TAC. The Star showed the highest value $(6345 \pm 601 \mu \mathrm{mol}$ of TE/100 g FW), 2.8-fold higher than Snowchaser, which presented the lowest $(2231 \pm 131 \mu \mathrm{mol}$ of TE/100 g FW). Cristina Blue and Stella Blue (5513 \pm 580 and $5251 \pm 534 \mu \mathrm{mol}$ of TE/100 g FW, respectively) displayed intermediate values with no significant differences.

Kalt et al. [74] determined the antioxidant capacity of 20 blueberry varieties (Bluecrop, Duke, Brigitta, Bluejay, Legacy and Sampson, among others), whose average antioxidant activity was $4900 \mu \mathrm{mol}$ of TE/100 g FW. Bunea et al. [31] reported ORAC values for Bluegold, Nui, Darrow, Legacy, Nelson, Hanna's Choice and Toro varieties between 2036-3458 $\mu \mathrm{mol}$ TE/100 g FW, with Hanna's Choice standing out for having the lowest antioxidant activity, and Toro the highest (Table 2). Wang et al. [73] estimated the ORAC value for 14 different varieties between 2627 and $6747 \mu \mathrm{mol}$ TE/100 g FW, with Northland standing out as the variety with the highest antioxidant capacity, and Berkley with the lowest (Table 2). The present study showed that Snowchaser's antioxidant value is within the range previously described for Berkeley, Brie G Kobita, Bluegold, Nui, Darrow and Hanna's Choice varieties, whereas Star is similar to North Country (Figure 1 and Table 2). Stella Blue and Cristina Blue values agree with the Blomidom, Chipava and Send a Blow varieties.

Star, Cristina Blue and Stella Blue ORAC values were in the range of other edible fruits such as blackberry (6250-8550 $\mu \mathrm{mol}$ TE/100 g FW), honeyberry (5200-6800 $\mu \mathrm{mol}$ TE/100 g FW) and red grape $(3700-13,500 \mu \mathrm{mol} \mathrm{TE} / 100 \mathrm{~g} \mathrm{FW})[75,76]$. Other berries, such as cranberry and elderberry, showed higher ORAC values (7000 and 20,500 $\mu \mathrm{mol} \mathrm{TE} / 100 \mathrm{~g}$ FW, respectively) [56].

The antioxidant capacity of the four blueberry anthocyanin-rich extracts was positively correlated with the TAC $(r=0.72 ; p<0.0001)$, as assessed by the ORAC assay, agreeing with other reports $[62,75,77]$. This shows that the high antioxidant activity of the extracts can, in fact, be attributed to the TAC. Thus, a subsequent linear regression analysis was performed to evaluate the effect of the TAC in the tested blueberries on their antioxidant activity, obtaining the model in Equation (1):

$$
\text { ORAC }=3006.64+2.23 \times \text { TAC }
$$

The model had an average fit-only $R^{2}=0.52$ - showing that about half of the variability in the data is explained by other variables. However, both the model and the TAC model parameters were statistically significant $(p<0.0001)$. Borges et al. [78] reported that the anthocyanins are 
indeed the major contributor to blueberries' antioxidant activity (84\%). They showed that a broad spectrum of anthocyanins (15 major contributors) are responsible: delphinidin-3-Ogalactoside $(\approx 20 \%)$, cyanidin-3-O-galactoside and delphinidin-3-O-arabinoside $(\approx 15 \%)$, petunidin-3-Ogalactoside $(\approx 12 \%)$, malvidin-3-O-galactoside $(\approx 12 \%)$, malvidin-3-O-arabinoside $(\approx 9 \%)$.

Table 2. Antioxidant activity of different blueberry extracts (V. corymbosum).

\begin{tabular}{cccc}
\hline Variety & $\begin{array}{c}\text { ORAC } \\
(\mu \text { mol TE/100g FW) }\end{array}$ & Cropfile & References \\
\hline Blomidom & $5538 \pm 388$ & USA & {$[73]$} \\
Northland & $6747 \pm 121$ & USA & {$[73]$} \\
Northblue & $4976 \pm 722$ & USA & {$[73]$} \\
North Country & $6265 \pm 699$ & USA & {$[73]$} \\
Chipava & $5856 \pm 165$ & USA & {$[73]$} \\
Elliott & $4098 \pm 436$ & USA & {$[73]$} \\
Darrow & $3994 \pm 522$ & USA & {$[73]$} \\
Bluecrop & $4491 \pm 190$ & USA & {$[73]$} \\
Primary Operation Blue & $3649 \pm 473$ & USA & {$[73]$} \\
Send a Blow & $5070 \pm 179$ & USA & {$[73]$} \\
Berkley & $2627 \pm 364$ & USA & {$[73]$} \\
JK-M7 & $4114 \pm 344$ & USA & {$[73]$} \\
Brie G Kobita & $2737 \pm 394$ & USA & {$[73]$} \\
Duke & $3145 \pm 263$ & USA & {$[73]$} \\
Bluegold & $2121 \pm 326$ & Romania & {$[31]$} \\
Nui & $2235 \pm 677$ & Romania & {$[31]$} \\
Darrow & $2543 \pm 219$ & Romania & {$[31]$} \\
Legacy & $2899 \pm 531$ & Romania & {$[31]$} \\
Nelson & $3027 \pm 474$ & Romania & {$[31]$} \\
Hanna's Choice & $2036 \pm 223$ & Romania & {$[31]$} \\
Toro & $3458 \pm 325$ & Romania & {$[31]$} \\
\hline & & &
\end{tabular}

\subsection{Anthocyanin Profile}

A total of 25 different anthocyanin compounds were identified by UHPLC-MS/MS in the four blueberry varieties (Table 3). Star and Stella Blue presented the highest diversity on the anthocyanin profile (22 and 23 different compounds, respectively). Nineteen different anthocyanins were described for Cristina Blue and Snowchaser. The previously described anthocyanin profiles vary between 10-23 different compounds, depending on the variety, with Brigitta having the highest number $[21,31,38,41,76,79]$. Therefore, the varieties analysed in the present study are among the blueberry varieties with highest diversity of anthocyanin compounds.

Star, Stella blue, Snowchaser and Cristina blue presented five out of the six most frequently naturally occurring anthocyanidins on their profile (cyanidin, delphinidin, peonidin, petunidin and malvidin), showing a great diversity (Table 3 ). Most of the varieties previously reported present these anthocyanidins, except for Bluegold, Brigitta and Legacy cultivated in Chile; Rocio and the two experimental varieties (V2 and V3) grown in Spain and Bluecrop cultivated in USA, which did not contain peonidin $[36,41,80]$. Anthocyanins present in the varieties studied were the glucoside, arabinoside, rutinoside, acetyl and malonyl forms (Table 3). Additionally, xyloside, p-coumaroyl and caffeoyl forms had been previously identified in Brigitta and Bluecrop grown in Chile and Macedonia, respectively [31,79]. However, in the hot climate of Spain the acetylated forms of anthocyanins had been found in experimental cultivars, V2 and V3, only [41]. 
Table 3. Tentative identification of different anthocyanins in the blueberry varieties analysed.

\begin{tabular}{|c|c|c|c|c|c|c|c|}
\hline $\begin{array}{l}\text { Retention Time } \\
\text { (min) }\end{array}$ & Compounds & $\begin{array}{c}\text { Molecular Formula } \\
\left(\mathrm{M}^{+}\right)\end{array}$ & $\begin{array}{l}\text { Calculated } \\
\text { Mass }(m / z)\end{array}$ & $\begin{array}{c}\text { Accurate } \\
\text { Mass }(m / z)\end{array}$ & $\begin{array}{r}\text { Error } \\
(\mathrm{ppm})\end{array}$ & MS/MS Fragments & Variety \\
\hline 4.03 & Delphinidin-3-O-galactoside & $\mathrm{C}_{21} \mathrm{H}_{21} \mathrm{O}_{12}$ & 465.1028 & 465.1023 & -1.0441 & 303.0501 & $\mathrm{~A} ; \mathrm{B} ; \mathrm{C} ; \mathrm{D}$ \\
\hline 4.30 & Delphinidin-3-O-glucoside * & $\mathrm{C}_{21} \mathrm{H}_{21} \mathrm{O}_{12}$ & 465.1028 & 465.1025 & -0.4535 & 303.0502 & $\mathrm{~A} ; \mathrm{B} ; \mathrm{C} ; \mathrm{D}$ \\
\hline 4.44 & Cyanidin-3-galactoside * & $\mathrm{C}_{21} \mathrm{H}_{21} \mathrm{O}_{11}$ & 449.1078 & 449.1073 & -1.1349 & 287.0552 & $\mathrm{~A} ; \mathrm{B} ; \mathrm{C} ; \mathrm{D}$ \\
\hline 4.47 & Delphinidin-3-O-arabinoside & $\mathrm{C}_{20} \mathrm{H}_{19} \mathrm{O}_{11}$ & 435.0922 & 435.0918 & -0.8334 & 303.0501 & $\mathrm{~A} ; \mathrm{B} ; \mathrm{C} ; \mathrm{D}$ \\
\hline 4.60 & Cyanidin-3-O-glucoside* & $\mathrm{C}_{21} \mathrm{H}_{21} \mathrm{O}_{11}$ & 449.1078 & 449.1073 & -1.1349 & 287.0543 & $\mathrm{~A} ; \mathrm{B} ; \mathrm{C} ; \mathrm{D}$ \\
\hline 4.65 & Petunidin-3-O-galactoside & $\mathrm{C}_{22} \mathrm{H}_{23} \mathrm{O}_{12}$ & 479.1184 & 479.1180 & -0.9383 & 317.0658 & $\mathrm{~A} ; \mathrm{B} ; \mathrm{C} ; \mathrm{D}$ \\
\hline 4.68 & Cyanidin-3-O-rutinoside & $\mathrm{C}_{27} \mathrm{H}_{31} \mathrm{O}_{15}$ & 595.1658 & 595.1650 & -1.1945 & 449.10784/ 287.05501 & $\mathrm{D}$ \\
\hline 4.73 & Cyanidin-3-O-arabinoside & $\mathrm{C}_{20} \mathrm{H}_{19} \mathrm{O}_{10}$ & 419.0973 & 419.0968 & -1.1173 & 287.0550 & $\mathrm{~A} ; \mathrm{B} ; \mathrm{C} ; \mathrm{D}$ \\
\hline 4.76 & Petunidin-3-O-glucoside & $\mathrm{C}_{22} \mathrm{H}_{23} \mathrm{O}_{12}$ & 479.1184 & 479.1179 & -1.1346 & 317.0645 & $\mathrm{~A} ; \mathrm{B} ; \mathrm{C} ; \mathrm{D}$ \\
\hline 7.77 & Petunidin-3-O-rutinoside & $\mathrm{C}_{28} \mathrm{H}_{33} \mathrm{O}_{16}$ & 625.1763 & 625.1766 & 0.4215 & 479.1180 & $\mathrm{D}$ \\
\hline 4.89 & Peonidin-3-O-galactoside & $\mathrm{C}_{22} \mathrm{H}_{23} \mathrm{O}_{11}$ & 463.1235 & 463.1230 & -1.1500 & 301.0708 & $\mathrm{~A} ; \mathrm{B} ; \mathrm{C} ; \mathrm{D}$ \\
\hline 4.89 & Petunidin-3-O-arabinoside & $\mathrm{C}_{21} \mathrm{H}_{21} \mathrm{O}_{11}$ & 449.1078 & 449.1073 & -1.1300 & 317.0656 & $\mathrm{~A} ; \mathrm{B} ; \mathrm{C} ; \mathrm{D}$ \\
\hline 4.99 & Malvidin-3-O-galactoside & $\mathrm{C}_{23} \mathrm{H}_{25} \mathrm{O}_{12}$ & 493.1341 & 493.1335 & -1.0913 & 331.0812 & $\mathrm{~A} ; \mathrm{B} ; \mathrm{C} ; \mathrm{D}$ \\
\hline 4.99 & Peonidin-3-O-glucoside * & $\mathrm{C}_{22} \mathrm{H}_{23} \mathrm{O}_{11}$ & 463.1235 & 463.1231 & -0.7546 & 301.0694 & $\mathrm{~A} ; \mathrm{B} ; \mathrm{C} ; \mathrm{D}$ \\
\hline 5.04 & Peonidin-3-O-rutinoside & $\mathrm{C}_{28} \mathrm{H}_{33} \mathrm{O}_{15}$ & 609.1814 & 609.1804 & -1.7904 & 301.0691 & $\mathrm{~A} ; \mathrm{B} ; \mathrm{C} ; \mathrm{D}$ \\
\hline 5.10 & Malvidin-3-O-glucoside * & $\mathrm{C}_{23} \mathrm{H}_{25} \mathrm{O}_{12}$ & 493.1341 & 493.1336 & -0.8437 & 331.0802 & $\mathrm{~A} ; \mathrm{B} ; \mathrm{C} ; \mathrm{D}$ \\
\hline 5.19 & Cyanidin-3-(6"-acetyl) galactoside & $\mathrm{C}_{23} \mathrm{H}_{23} \mathrm{O}_{12}$ & 491.1184 & 491.1181 & -0.6047 & 287.0551 & $A ; C$ \\
\hline 5.22 & Malvidin-3-O-arabinoside & $\mathrm{C}_{22} \mathrm{H}_{23} \mathrm{O}_{11}$ & 463.1235 & 463.1231 & -0.9568 & 331.0813 & $\mathrm{~A} ; \mathrm{B} ; \mathrm{C} ; \mathrm{D}$ \\
\hline 5.33 & Delphinidin-3-(6" -acetyl) glucoside & $\mathrm{C}_{23} \mathrm{H}_{23} \mathrm{O}_{13}$ & 507.1133 & 507.1133 & -0.7986 & 303.0497 & A \\
\hline 5.33 & Petunidin-3-(6"-acetyl) galactoside & $\mathrm{C}_{24} \mathrm{H}_{25} \mathrm{O}_{13}$ & 521.1290 & 521.1236 & -1.1710 & 317.0657 & $\mathrm{~A} ; \mathrm{B} ; \mathrm{D}$ \\
\hline 5.39 & Cyanidin-3-(6-acetyl) glucoside & $\mathrm{C}_{23} \mathrm{H}_{23} \mathrm{O}_{12}$ & 491.1184 & 491.1182 & -0.3561 & 287.0551 & $\mathrm{~A} ; \mathrm{C} ; \mathrm{D}$ \\
\hline 5.47 & Malvidin-3-(6"-acetyl) galactoside & $\mathrm{C}_{25} \mathrm{H}_{27} \mathrm{O}_{13}$ & 535.1145 & 535.1441 & -0.9590 & 331.0801 & $\mathrm{D}$ \\
\hline 5.48 & Petunidin-3-(6" -acetyl) glucoside & $\mathrm{C}_{24} \mathrm{H}_{25} \mathrm{O}_{13}$ & 521.1290 & 521.1289 & -0.2340 & 317.0651 & $\mathrm{~A} ; \mathrm{B} ; \mathrm{C} ; \mathrm{D}$ \\
\hline 5.53 & Peonidin-3-(6"-acetyl) glucoside & $\mathrm{C}_{4}{ }_{4} \mathrm{H}_{25} \mathrm{O}_{12}$ & 505.1341 & 505.1343 & 0.4501 & 301.0707 & $\mathrm{~A} ; \mathrm{B} ; \mathrm{C} ; \mathrm{D}$ \\
\hline 5.58 & Delphinidin-3-(6"-malonyl) glucoside & $\mathrm{C}_{24} \mathrm{H}_{23} \mathrm{O}_{15}$ & 551.1032 & 551.1034 & 0.4419 & 303.0501 & $\mathrm{~A} ; \mathrm{B} ; \mathrm{D}$ \\
\hline
\end{tabular}

${ }^{*}$ Identified with pure standards; A: Star; B: Snowchaser; C: Cristina Blue and D: Stella Blue. 
Most of the anthocyanin compounds were present in all four varieties under study (Table 3 ). However, cyanidin-3-rutinoside, petunidin-3-rutinoside and malvidin-3-(6" -acetyl) galactoside were only identified in Stella blue (Table 3). As far as we know, this is the first time that cyanidin-3-rutinoside has been identified in blueberry. It could be proposed as a marker of the Stella Blue variety. This compound had been previously identified in strawberry, blackberry, sweet berry, Chilean guava (Ugni molinae) and plum [21,23,81]. Petunidin-3-rutinoside was previously described in Brigitta blueberry variety, while malvidin-3-(6" -acetyl) galactoside was also identified in the Arlen, Legacy, Lenoir, O’Neal, Pamlico, Sampson, Toro and Bluecrop varieties [21,38,79].

Delphinidin-3-(6" -acetyl) glucoside was only identified in Star (Table 3), although it had previously been detected in varieties, such as Brigitta, Arlen, Legacy, Lenoir, O'Neal, Pamlico, Sampson, Bluecrop, and Ozarkblue [21,38,76]. Cyanidin-3-(6"-acetyl) galactoside was detected in Star and Cristina Blue (Table 3). As far as we know, this compound had only been detected previously in a non-declared blueberry variety cultivated in USA [81]. Petunidin-3-(6"-acetyl) galactoside was identified in Star, Snowchaser and Stella Blue (Table 3), and it was only previously reported in a non-declared blueberry variety grown in Slovenia [82]. Similarly, delphinidin-3-(6"-malonyl) glucoside was also determined in Star, Snowchaser and Stella Blue (Table 3). Conversely, it was only reported in the abovementioned non-declared blueberry variety cultivated in USA [81]. Although peonidin-3-O-glucoside and peonidin-3-O-rutinoside were identified in the four varieties studied, they were only reported in the abovementioned blueberry varieties grown in USA and Slovenia, and in Brigitta, respectively [81,82]. Peonidin glycosides usually reported in blueberries are galactoside and arabinoside [21,31,38,76,79,81,83]. Therefore, we could propose Cyanidin-3-(6"-acetyl) galactoside as a marker for Star and Cristina Blue; petunidin-3-(6" -acetyl) galactoside and delphinidin-3-(6"-malonyl) glucoside as markers for Star, Snowchaser and Stella Blue, and peonidin-3-O-glucoside and peonidin-3-O-rutinoside markers for Star, Snowchaser, Cristina Blue and Stella Blue, including the previously-reported Brigitta for the latter compound.

\subsection{Antibacterial Activity}

Table 4 presents the minimum inhibitory concentration (MIC) of the anthocyanin-rich extracts from the four varieties of blueberries against the strains isolated from urinary tract infections (UTI) and standard strains. All varieties significantly inhibited the growth of the eight strains (five UTI strains and three standard strains) when compared with the negative control (70\% methanol), with MICs ranging from $0.4 \mathrm{mg} / \mathrm{mL}$ (in the case of Stella Blue extract against UTI P. aeruginosa) to $9.5 \mathrm{mg} / \mathrm{mL}$ (in the case of all extracts against UTI K. pneumoniae ssp. pneumoniae) (Table 4).

Our results show that the 4 anthocyanin-rich extracts were most effective against $P$. aeruginosa among the bacteria isolated from UTI patients. This is surprising, because P. aeruginosa was the strain most resistant to the positive control general wide-spectrum antibiotic Gentamicin. This finding suggests the need to further explore the potential of anthocyanins from blueberries as a novel approach to controlling some antibiotic resistant UTI strains, especially since we are currently facing the problem of the emergence and spread of antibiotic-resistant strains. UTI can, however, be caused by many pathogens, with uropathogenic E. coli as the main culprit identified in about $80 \%$ of the clinical cases [84]. In this respect, the four anthocyanin-rich extracts were less effective against K. pneumoniae UTI (the most resistant strain), followed by E. coli UTI and ATCC strains. These results were later confirmed by minimum bactericidal concentration (MBC) testing (Table 5).

The $\mathrm{MBC}$ ranged from $1.0 \mathrm{mg} / \mathrm{mL}$ (in the case of extracts against UTI P. aeruginosa and Stella Blue against UTI Micrococcus spp.) to $9.5 \mathrm{mg} / \mathrm{mL}$ (in the case of all extracts against UTI K. pneumoniae ssp. pneumoniae, Star against UTI E. coli; Stella Blue against ATCC E. coli and Star against L. monocytogenes) (Table 5). The blueberry anthocyanin-rich extracts had a statistically similar effect to the synthetic generic antibiotic $(0.4 \mathrm{mg} / \mathrm{mL}$ Gentamicin) used as positive control against all five UTI strains tested, and only against E. coli from the standard ATCC strains. The effect was weaker than the positive control against $S$. Enteritidis and L. monocytogenes, but significant, nonetheless. Hence, the extracts 
were the most effective against $P$. aeruginosa $(\mathrm{MBC}=1.0 \mathrm{mg} / \mathrm{mL})$, while the smallest effect was against K. pneumoniae $(\mathrm{MBC}=9.5 \mathrm{mg} / \mathrm{mL})$. Similarly, K. pneumoniae showed to be resistant to anthocyanins-rich pomegranate extracts [85].

The effect of the four anthocyanin-rich extracts against the UTI strains tested as a group was compared with the ATCC strains (data not shown). The results suggested that each of the four extracts are approximately 3-fold less effective against UTI Gram-negatives than against ATCC Gram-negatives. The same remark could be made when considering the anthocyanin-rich extracts as one group only, supporting all the observations made within this study. However, this can be seen only in the case of Cristina Blue for Gram-positives, and not at all for anthocyanin-rich extracts as a whole. The differences were also evaluated between the tested Gram-negatives and Gram-positives. The effect of the four blueberry varieties did not vary between the two groups. However, the extracts were 3-fold less effective against the UTI than the ATCC within the Gram-negatives group, consistent with the prior observation. This observation is in line with the reports of Dorneanu et al. [59] that show a greater resistance of Gram-negative UTI strains to Aronia melanocarpa anthocyanin extracts compared to Gram-positives. Even though the Gram-negative UTI strains appear to be consistently more resistant to the anthocyanins from blueberries, the main limitation of this study is that only one Gram-positive strain was isolated from the UTI compared to four Gram-negatives. Thus, the data on Gram-positives is rather limited. This could open future research paradigms for the antibacterial activity of anthocyanins.

Table 6 shows the Pearson correlation between the antibacterial activity of the four anthocyanin-rich extracts and the TAC and ORAC. Although positive correlations between the MIC, MBC and the TAC were obtained, it reached statistical significance in the case of the UTI $\beta$-Haemolytic E. coli MBC only. Interestingly, the MIC of $S$. Enteritidis showed an inverse relation with the TAC; although high, it was not significant. No correlation was observed between the antibacterial and antioxidant activity. This agrees with other studies [55], although other authors have found a significant correlation between antibacterial activity and polyphenolic content in berries [32]. Linear regression analysis was performed following the results of the Pearson correlation. The model equations and the goodness of fit parameters are presented in Table 7.

The mechanism of bacterial inhibition by berry compounds is an accumulation of direct and indirect effects [86]. The direct action is the interference of phytochemicals with the bacterial cell membrane that leads to the inactivation of crucial enzymes. The indirect effect, on the other hand, is related to the nutrient availability or genomic expression, both impairing the metabolism and the normal functioning of the bacteria. Blueberry anthocyanins act mainly by inhibiting gene transcription, disrupting the cell membrane structure and energy transport, thus inhibiting their growth and reproduction $[51,52,60,87]$. Blueberry extracts were observed to affect the transcription of up to seven genes in the bacterial cell $[51,60]$. These genes had critical roles in the internal and external channels of cell membranes. Among these was the TolC porin protein that controls the outer membrane channel. It also has a central role in pumping out antibacterial agents such as antibiotics and detergents. Other studies showed that blueberry anthocyanins distorted the membrane morphology and caused aggregation and leakage of cellular contents of E. coli, S. Typhimurium, S. Enteritidis, L. monocytogenes and $P$. aeruginosa $[46,52,60,87]$. The anthocyanins from blueberries might also interfere with the activity of several enzymes regulating the bacterial cell's metabolic functions [45,52]. They could inactivate the alkaline phosphatase (AKP), thus preventing cell differentiation, and they may affect the $\mathrm{Ca}^{2+}$ metabolism as well. Additionally, blueberry anthocyanins might lower the levels of ATPase, increasing the efflux of ATP from the cytoplasm of pathogens, thus inhibiting respiratory metabolism and affecting the energy supply. 
Table 4. Minimum inhibitory concentration (MIC) of anthocyanin-rich extracts from the four varieties of blueberries, expressed in mg/mL.

\begin{tabular}{|c|c|c|c|c|c|c|c|c|}
\hline \multirow{3}{*}{$\begin{array}{r}\text { Type of Strain } \\
\begin{array}{r}\text { Gram staining } \\
\text { of the strains }\end{array} \\
\text { Strains }\end{array}$} & \multicolumn{5}{|c|}{ UTI Strains } & \multicolumn{3}{|c|}{ ATCC Standard Strains } \\
\hline & \multicolumn{4}{|c|}{ Gram-negative } & \multirow{2}{*}{$\begin{array}{l}\text { Gram-positive } \\
\text { Micrococcus spp. }\end{array}$} & \multicolumn{2}{|c|}{ Gram-negative } & \multirow{2}{*}{$\begin{array}{c}\text { Gram-positive } \\
\text { Listeria monocytogenes } \\
\text { ATCC } 19114\end{array}$} \\
\hline & $\begin{array}{l}\text { Klebsiella pneumoniae } \\
\text { ssp. pneumoniae }\end{array}$ & $\begin{array}{c}\text { Providencia } \\
\text { stuartii }\end{array}$ & $\begin{array}{l}\text { Escherichia coli } \\
\beta \text {-Haemolytic }\end{array}$ & $\begin{array}{c}\text { Pseudomonas } \\
\text { aeruginosa }\end{array}$ & & $\begin{array}{l}\text { Escherichia coli } \\
\text { ATCC } 25922\end{array}$ & $\begin{array}{c}\text { Salmonella Enteritidis } \\
\text { ATCC } 13076\end{array}$ & \\
\hline Cristina Blue & $9.52 \pm 0 \mathrm{Ac}$ & $1.78 \pm 0.65^{\mathrm{A}, \mathrm{a}}$ & $3.74 \pm 1.372^{\mathrm{A}, \mathrm{b}}$ & $0.85 \pm 0.31^{\mathrm{A}, \mathrm{a}}$ & $1.41 \pm 0.65^{\mathrm{A}, \mathrm{a}}$ & $3.74 \pm 1.37^{\mathrm{A}, \mathrm{b}}$ & $2.16 \pm 0^{\mathrm{C}, \mathrm{a}}$ & $4.54 \pm 0^{\mathrm{D}, \mathrm{b}}$ \\
\hline Star & $9.52 \pm 0 \mathrm{Ad}$ & $1.78 \pm 0.65^{\mathrm{A}, \mathrm{a}, \mathrm{b}}$ & $3.74 \pm 1.372^{A, c}$ & $0.49 \pm 0^{\mathrm{A}, \mathrm{a}}$ & $2.57 \pm 1.79 \mathrm{~A}, \mathrm{~b}, \mathrm{c}$ & $3.74 \pm 1.37 \mathrm{~A}, \mathrm{c}$ & $1.03 \pm 0^{\mathrm{B}, \mathrm{a}, \mathrm{b}}$ & $2.16 \pm 0^{\mathrm{C}, \mathrm{a}, \mathrm{b}, \mathrm{c}}$ \\
\hline Snowchaser & $9.52 \pm 0 \mathrm{Ad}$ & $1.78 \pm 0.65^{\mathrm{A}, \mathrm{a}, \mathrm{b}}$ & $3.74 \pm 1.372^{\mathrm{A}, \mathrm{c}}$ & $0.58 \pm 0.41^{\mathrm{A}, \mathrm{a}}$ & $1.78 \pm 0.65^{\mathrm{A}, \mathrm{a}, \mathrm{b}}$ & $3.74 \pm 1.37^{\mathrm{A}, \mathrm{c}}$ & $1.78 \pm 0.65^{C, a, b}$ & $2.16 \pm 0^{\mathrm{C}, \mathrm{b}}$ \\
\hline Stella Blue & $9.52 \pm 0 \mathrm{Ad}$ & $1.78 \pm 0.65^{\mathrm{A}, \mathrm{a}, \mathrm{b}}$ & $3.74 \pm 1.372 \mathrm{~A}, \mathrm{c}$ & $0.40 \pm 0.15^{\mathrm{A}, \mathrm{a}}$ & $0.76 \pm 0.46^{\mathrm{A}, \mathrm{a}, \mathrm{b}}$ & $3.74 \pm 1.37^{\mathrm{A}, \mathrm{c}}$ & $2.16 \pm 0^{\mathrm{C}, \mathrm{b}}$ & $1.41 \pm 0.653^{\mathrm{B}, \mathrm{a}, \mathrm{b}}$ \\
\hline
\end{tabular}

Note: The data are presented as mean $\pm \mathrm{SD}, n=3$. Different uppercase letters indicate statistically significant differences on the columns, and therefore differences among the samples, methanol, the solvent used for the dilution of the lyophilised anthocyanins, while the positive control was Gentamicin (with the initial concentration of stock solution of $0.4 \mathrm{mg} / \mathrm{mL}$ ).

Table 5. Minimum bactericidal concentration (MBC) of anthocyanin-rich extracts from the four varieties of blueberries, expressed in $\mathrm{mg} / \mathrm{mL}$.

\begin{tabular}{|c|c|c|c|c|c|c|c|c|}
\hline \multirow{3}{*}{$\begin{array}{l}\text { Type of Strain } \\
\begin{array}{r}\text { Gram staining } \\
\text { of the strains }\end{array} \\
\text { Strains }\end{array}$} & \multicolumn{5}{|c|}{ UTI Strains } & \multicolumn{3}{|c|}{ ATCC Standard Strains } \\
\hline & \multicolumn{4}{|c|}{ Gram-negative } & \multirow{2}{*}{$\begin{array}{l}\text { Gram-positive } \\
\text { Micrococcus } \\
\text { spp. }\end{array}$} & \multicolumn{2}{|c|}{ Gram-negative } & \multirow{2}{*}{$\begin{array}{c}\text { Gram-positive } \\
\text { Listeria monocytogenes } \\
\text { ATCC } 19114\end{array}$} \\
\hline & $\begin{array}{l}\text { Klebsiella pneumoniae } \\
\text { ssp. pneumoniae }\end{array}$ & $\begin{array}{c}\text { Providencia } \\
\text { stuartii }\end{array}$ & $\begin{array}{l}\text { Escherichia coli } \\
\beta \text {-Haemolytic }\end{array}$ & $\begin{array}{l}\text { Pseudomonas } \\
\text { aeruginosa }\end{array}$ & & $\begin{array}{l}\text { Escherichia coli } \\
\text { ATCC } 25922\end{array}$ & $\begin{array}{c}\text { Salmonella Enteritidis } \\
\text { ATCC } 13076\end{array}$ & \\
\hline Cristina Blue & 9.52 & 4.54 & 4.54 & 1.03 & 2.16 & 4.54 & 2.16 & 4.54 \\
\hline Star & 9.52 & 4.54 & 9.52 & 1.03 & 4.54 & 4.54 & 4.54 & 9.52 \\
\hline Snowchaser & 9.52 & 2.16 & 4.54 & 1.03 & 2.16 & 4.54 & 4.54 & 4.54 \\
\hline Stella Blue & 9.52 & 2.16 & 4.54 & 1.03 & 1.03 & 9.52 & 2.16 & 2.16 \\
\hline
\end{tabular}


Table 6. Pearson correlation matrix of the minimum inhibitory concentration (MIC) and minimum bactericidal concentration (MBC), with the total anthocyanin content (TAC) of the four varieties of blueberries and the antioxidant capacity, as assessed by the ORAC.

\begin{tabular}{|c|c|c|c|c|c|c|c|c|}
\hline \multirow{3}{*}{$\begin{array}{r}\text { Type of strain } \\
\begin{array}{r}\text { Gram staining } \\
\text { of the strains }\end{array} \\
\text { Strains }\end{array}$} & \multicolumn{5}{|c|}{ UTI Strains } & \multicolumn{3}{|c|}{ ATCC Standard Strains } \\
\hline & \multicolumn{4}{|c|}{ Gram-negative } & \multirow{2}{*}{$\begin{array}{l}\text { Gram-positive } \\
\text { Micrococcus } \\
\text { spp. }\end{array}$} & \multicolumn{2}{|c|}{ Gram-negative } & \multirow{2}{*}{$\begin{array}{c}\text { Gram-positive } \\
\text { Listeria monocytogenes } \\
\text { ATCC } 19114\end{array}$} \\
\hline & $\begin{array}{l}\text { Klebsiella pneumoniae } \\
\text { ssp. pneumoniae }\end{array}$ & $\begin{array}{l}\text { Providencia } \\
\text { stuartii }\end{array}$ & $\begin{array}{l}\text { Escherichia coli } \\
\beta \text {-Haemolytic }\end{array}$ & $\begin{array}{l}\text { Pseudomonas } \\
\text { aeruginosa }\end{array}$ & & $\begin{array}{l}\text { Escherichia coli } \\
\text { ATCC } 25922\end{array}$ & $\begin{array}{c}\text { Salmonella Enteritidis } \\
\text { ATCC } 13076\end{array}$ & \\
\hline TAC & 0.69 & -0.24 & -0.81 & -0.08 & 0.86 & 0.69 & 0.96 & -0.22 \\
\hline ORAC & 0.13 & -0.04 & -0.25 & 0.18 & 0.39 & 0.70 & 0.56 & 0.15 \\
\hline
\end{tabular}

Values in bold are different to 0 with a significance level of $\alpha=0.05$. 
Table 7. Regression of antibacterial activity (MIC and MBC) variables and the total anthocyanin content (TAC) of the four varieties of blueberries, and the antioxidant capacity, as assessed by the ORAC.

\begin{tabular}{ccc}
\hline Linear Regression Equations & $\begin{array}{c}\text { Goodness of Fit, } \\
\boldsymbol{R}^{\mathbf{2}}\end{array}$ & $\begin{array}{c}\text { Statistical Significance of the Model, } \\
\boldsymbol{p}\end{array}$ \\
\hline MIC S. ATCC $=1.74-1.46 \times 10^{-3} \times \mathrm{TAC}+2.69 \times 10^{-4} \times$ ORAC & 1.00 & 0.002 \\
MBC E. UTI $=3.64+5.83 \times 10^{-3} \times \mathrm{TAC}-6.00 \times 10^{-4} \times$ ORAC & 0.99 & 0.023 \\
MBC S. ATCC $=5.64+3.62 \times 10^{-3}-1.12 \times 10^{-3} \times$ ORAC & 0.99 & 0.033 \\
MBC E. UTI $=2.03+4.33 \times 10^{-3} \times$ TAC & 0.92 & 0.039 \\
\hline
\end{tabular}

Where: The first letter in the abbreviation stands for the variable correlated: MIC-minimum inhibitory concentration; $\mathrm{MBC}=$ minimum bactericidal concentration; the letters afterwards show the strain tested: E.-Escherichia coli; S.-Salmonella Enteritidis; while the type of isolation is last: UTI—strain isolated from urinary tract infection; ATCC—-standard strain.

Furthermore, sublethal concentrations of blueberry pomace extracts significantly affected other factors related to the virulence and pathogenicity of pathogens. They decreased the cell surface hydrophobicity of $S$. Typhimurium, together with its auto-aggregation, cellular motility, colonisation and invasion capabilities [87]. Similarly, compounds in purified proanthocyanins from cranberry extracts inhibited the agglutination of E. coli and K. pneumoniae [88]. However, this effect was strain- specific and dose-dependent $[53,88]$. Blueberry extracts affected the growth of $E$. coli and P. aeruginosa, and they were able to significantly inhibit their biofilm formation and bacterial adhesion [50] — both important factors in their surface colonisation and infection [54]. Low concentrations of blueberry extracts proved to be more effective in inhibiting the biofilm formation, because a higher anthocyanin concentration could increase the production of exopolysaccharides in the presence of environmental stress, enhancing the protection of bacteria [50]. The specific mechanism of blueberry anthocyanins needs, therefore, to be further explored and qualified. Similar significant results were reported for anthocyanins from blueberries in general against $E$. coli $[47,50,89]$ and L. monocytogenes foodborne pathogens $[47,52]$, and for UTI pathogens E. coli $[50,57,58]$ and P. aeruginosa [50].

Comparing our results with others already reported, a lower inhibition of blueberry anthocyanins was observed for E. coli O157:H7 (MIC $=173.08 \mathrm{mg} / \mathrm{mL}$ ) [46]; of various blueberry cultivars (Highbush and Rabbiteye) extracts for E. coli (MIC $=20-35 \mathrm{mg} / \mathrm{mL}$ ) [32] and of blueberry fruit infusion for E. coli (MIC $=50 \mathrm{mg} / \mathrm{mL}$ ) [89]. Additionally, Sun et al. [52] obtained lower MICs and MBCs of $L$. monocytogenes and $S$. Enteritidis $(\mathrm{MIC}=0.27 \mathrm{mg} / \mathrm{mL} ; \mathrm{MBC}=0.53$ ) for blueberry anthocyanins. Other studies dealing with blueberry extracts presented MIC of L. monocytogenes ranging from 100 to $300 \mathrm{mg} / \mathrm{mL}$ and an MBC of 100 to $450 \mathrm{mg} / \mathrm{mL}$, while for $S$. Enteritidis, a MIC of 100 to $450 \mathrm{mg} / \mathrm{mL}$ and an $\mathrm{MBC}$ of 100 to $600 \mathrm{mg} / \mathrm{mL}$ [49,53]. However, Zhou et al. [53] also suggested that L. monocytogenes might be more resistant than $S$. Enteritidis. Other studies, on the contrary, showed that blueberry peel extracts were most effective against Gram-negative bacteria, and mainly against E. coli [90]. Zhou et al. [53] also observed a higher inhibition of Gram-negative $S$. Enteritidis compared to the Gram-positive L. monocytogenes by blueberry extracts, including anthocyanins and proanthocyanidins. This effect, however, was not observed in the present study.

Not only, therefore, do the results vary, depending how the berries are processed prior to extraction and the type of extraction solvent used [86,91], but also on their variety and the pedo-climatic conditions in which they were cultivated $[44,47-49,53,86]$. Additionally, many phenolic compounds from blueberries, anthocyanins included, do not only directly inhibit the growth and survival of bacteria, but they do affect their virulence factor and their antibiotic resistance $[47,51,52]$. This makes their antibacterial activity also dependent on the strain tested.

Both cranberries and blueberries share a similar anthocyanin profile [31,44,91,92]. It appears that the monoglycoside anthocyanins (such as: delphinidin-3-O-glucoside, petunidin-3-O-glucoside, cyanidin-3-O-glucoside, malvidin-3-O-glucoside, peonidin-3-O-glucoside), abundant in blueberries, might be the compounds with the highest antibacterial effect against $S$. Enteritidis and L. monocytogenes [44,48]. A mixture of anthocyanins may therefore be needed in order to inhibit pathogens successfully [60-62]. In addition, the anthocyanins may exert an antibacterial activity, 
because they have the double ability to donate protons, causing the hyper acidification of the plasma membrane, and to sequester electrons from the respiration process [47].

Blueberry extracts showed better antibacterial activities than those of raspberry and strawberry, but were generally lower than cranberry extracts [45]. However, anthocyanins and proanthocyanidins from black chokeberries and pure cyanidin-3-O-galactoside proved to be ineffective against standard strains of E. coli, S. enterica, L. monocytogenes nor P. aeruginosa [55]. This shows the importance of not only the berries' anthocyanin profile, but also of having a broad spectrum of active compounds that could act synergistically $[61,62]$. Results highly comparable to the present study were obtained in a parallel study on the effect of Aronia melanocarpa on a broad spectrum of UTI clinical isolates strains, including E. coli, P. aeruginosa and K. pneumoniae [59]. The MIC for the strains of interest ranged from $2.5 \mathrm{mg} / \mathrm{mL}$ to $10 \mathrm{mg} / \mathrm{mL}$.

The role of anthocyanins from berries (mostly cranberries and blueberries) in UTI prevention and/or treatment still remains unclear. They interfere in vitro with the most prevalent and important virulence factor-the adhesion—of uropathogenic E. coli $[46,50,58]$. To the best of our knowledge, there are no in vivo studies relevant to the antibacterial activity of anthocyanins from blueberries. However, Ibrahim et al. [93] showed that cranberry anthocyanin extracts $(200 \mathrm{mg} / \mathrm{kg}$ b.w aqueous and methanol extracts) were effective in treating UTI caused by E. coli O157:H7 in infected rats. Although the anthocyanin profiles are not exactly the same in blueberries and cranberries, we might expect a similar behaviour. Nevertheless, further in vitro and in vivo studies would be needed, to ascertain not only the inactivation mechanism, but also that the in vitro effects can be transferred to in vivo.

It appears that the concentration and type of anthocyanins reaching the urine of UTI patients might be insufficient to exert a quantifiable effect [88]. In this sense, Cochrane meta-analyses, including clinical studies, showed a lack of positive trials $[16,18]$, while the Spanish Urological Association concluded that there are no significant benefits compared with placebo, except for a very small effect in certain population subgroups [94]. However, the positive results in this and other in vitro studies $[50,57,58]$ seem to point out that the actual optimal extraction procedures, mixture formulations, dosage and bioavailability are not yet clear [88]. Moreover, anthocyanins in blueberries might target each individual uropathogenic strain in the wider spectrum of UTI pathogens differently, varying their response to treatment [88]. It becomes, therefore, important first to verify that the correct bacteria are targeted before randomised clinical testing, an objective addressed by this study. However, based on in vitro data alone no recommendation for clinical practice could possibly be formulated. Further studies are needed to understand properly the pharmacokinetics of anthocyanins from blueberries and to establish properly the correct doses, in order to achieve a preventive and/or therapeutic concentration in the urinary tract [88].

\section{Conclusions}

Our results show that Star, Cristina Blue and Stella Blue blueberry varieties cultivated in the hot climate of Southern Spain exhibited significantly higher TAC values than the richest variety in anthocyanins so far reported. Star showed the highest antioxidant activity value, followed by Cristina Blue, Stella Blue and Snowchaser. As far as we know, this is the first time that cyanidin-3-rutinoside has been identified in blueberry. We could propose cyanidin-3-(6"-acetyl) galactoside as a marker for Star and Cristina Blue; petunidin-3-(6"-acetyl) galactoside and delphinidin-3-(6"-malonyl) glucoside as markers for Star, Snowchaser and Stella Blue; and peonidin-3-O-glucoside and peonidin-3-O-rutinoside markers for Star, Snowchaser, Cristina Blue and Stella Blue, including the previously-reported Brigitta for the latter compound. The anthocyanin-rich extracts from the four varieties effectively inhibited all the tested UTI and standard strains, with MICs ranging from $0.4 \mathrm{mg} / \mathrm{mL}$ (in the case of Stella Blue extract against UTI P. aeruginosa) to $9.5 \mathrm{mg} / \mathrm{mL}$ (in the case of all extracts against UTI K. pneumoniae ssp. pneumoniae). They were surprisingly effective against the $P$. aeruginosa UTI strain, showing a possible new approach in the endeavour to seek new measures for controlling some antibiotic resistant UTI strains. To the best of our knowledge, this is the first study that has tested in vitro the antibacterial 
activity of blueberries against Klebsiella pneumoniae, Providencia stuartii and Micrococcus spp. strains isolated from UTI. Therefore, we have shown that the principal potential uropathogenic bacteria are in fact targeted by the anthocyanin-rich extracts from blueberries. Our results offered a first tentative insight into the potential spectrum of UTI pathogens affected by the anthocyanins in blueberries, highlighting the strain-specificity of the antibacterial effect.

Author Contributions: Conceptualization, A.B.C., M.C.G.-P., A.M.T., G.M.C., and A.M.R.; Methodology, A.B.C., M.M.-P.G., R.H.-O., M.C.G.-P., A.M.T., G.M.C., C.C.R., G.M.C., C.R.P., and F.C.; Formal analysis, A.B.C., M.M.-P.G.; G.M.C., C.R.P., F.C.; Data curation, A.B.C., M.M.-P.G., G.M.C.; Writing-original draft preparation, A.B.C., M.M.-P.G., R.H.-O., M.C.G.-P., A.M.T., and G.M.C.; Writing-review and editing, A.B.C., R.H.-O., M.C.G.-P., A.M.T.; A.M.R., and G.M.C.; Funding acquisition, A.B.C., M.C.G.-P., A.M.T., G.M.C., and A.M.R. All authors have read and agreed to the published version of the manuscript.

Funding: This research was funded by the University of Sevilla, VI Plan Propio de Investigación y Transferencia (VIPPIT-2019-I.5), and by the Regional Government (Grant for Research, 2017/AGR-167). EFSA funding under the EU-FORA Programme for Giorgiana M. Cătunescu's contribution in the present work.

Acknowledgments: Authors would like to thank Sabor de Huelva S.C.A. (Gorofres SAT), Fres González García S.L. and Driscoll's of Europe B.V. for providing the blueberries. We are also grateful to the Mass Spectrometry (Rocio Valderrama and M.E. Soria-Díaz) services (CITIUS) of the University of Seville for their assistance with the UHPLC-MS/MS Orbitrap analysis. Giorgiana M. Cătunescu gratefully acknowledges the EFSA funding under the EU-FORA Programme for her contribution in the present work. The contribution of Lăcrămioara Alina Nistor during the microbiological analyses is also acknowledged.

Conflicts of Interest: The authors declare no conflict of interest.

\section{References}

1. Tsuda, T. Dietary anthocyanin-rich plants: Biochemical basis and recent progress in health benefits studies. Mol. Nutr. Food Res. 2012, 56, 159-170. [CrossRef]

2. Jara-Palacios, M.J.; Santisteban, A.; Gordillo, B.; Hernanz, D.; Heredia, F.J.; Escudero-Gilete, M.L. Comparative study of red berry pomaces (blueberry, red raspberry, red currant and blackberry) as source of antioxidants and pigments. Eur. Food Res. Technol. 2019, 245, 1-9. [CrossRef]

3. Fibigr, J.; Satinsky, D.; Solich, P. A UHPLC method for the rapid separation and quantification of anthocyanins in acai berry and dry blueberry extracts. J. Pharm. Biomed. Anal. 2017, 143, 204-213. [CrossRef]

4. Kim, J.G.; Kim, H.L.; Kim, S.J.; Park, K.-S. Fruit quality, anthocyanin and total phenolic contents, and antioxidant activities of 45 blueberry cultivars grown in Suwon, Korea. J. Zhejiang Univ. Sci. B 2013, 14, 793-799. [CrossRef]

5. Reque, P.M.; Steffens, R.S.; Silva, A.M.D.; Jablonski, A.; Flôres, S.H.; Rios, A.D.O.; Jong, E.V.D. Characterization of blueberry fruits (Vaccinium spp.) and derived products. Food Sci. Technol. (Camp.) 2014, 34, 773-779. [CrossRef]

6. Ongkowijoyo, P.; Luna-Vital, D.A.; Gonzalez De Mejia, E. Extraction techniques and analysis of anthocyanins from food sources by mass spectrometry: An update. Food Chem. 2018, 250, 113-126. [CrossRef]

7. Bendokas, V.; Skemiene, K.; Trumbeckaite, S.; Stanys, V.; Passamonti, S.; Borutaite, V.; Liobikas, J. Anthocyanins: From plant pigments to health benefits at mitochondrial level. Crit. Rev. Food Sci. Nutr. 2019. [CrossRef]

8. Fernandes, I.; Faria, A.; Calhau, C.; De Freitas, V.; Mateus, N. Bioavailability of anthocyanins and derivatives. J. Funct. Foods 2014, 7, 54-66. [CrossRef]

9. Cassidy, A.; Bertoia, M.; Chiuve, S.; Flint, A.; Forman, J.; Rimm, E.B. Habitual intake of anthocyanins and flavanones and risk of cardiovascular disease in men. Am. J. Clin. Nutr. 2016, 104, 587-594. [CrossRef]

10. Cassidy, A.; Mukamal, K.J.; Liu, L.; Franz, M.; Eliassen, A.H.; Rimm, E.B. High anthocyanin intake is associated with a reduced risk of myocardial infarction in young and middle-aged women. Circulation 2013, 127, 188-196. [CrossRef]

11. McCullough, M.L.; Peterson, J.J.; Patel, R.; Jacques, P.F.; Shah, R.; Dwyer, J.T. Flavonoid intake and cardiovascular disease mortality in a prospective cohort of US adults. Am. J. Clin. Nutr. 2012, 95, 454-464. [CrossRef]

12. Zamora-Ros, R.; Knaze, V.; Luján-Barroso, L.; Slimani, N.; Romieu, I.; Touillaud, M.; Kaaks, R.; Teucher, B.; Mattiello, A.; Grioni, S.; et al. Estimation of the intake of anthocyanidins and their food sources in the 
European Prospective Investigation into Cancer and Nutrition (EPIC) study. Br. J. Nutr. 2011, 106, 1090-1099. [CrossRef]

13. De Pascual-Teresa, S.; Moreno, D.A.; García-Viguera, C. Flavanols and anthocyanins in cardiovascular health: A review of current evidence. Int. J. Mol. Sci. 2010, 11, 1679-1703. [CrossRef]

14. Howell, A.B. Bioactive compounds in cranberries and their role in prevention of urinary tract infections. Mol. Nutr. Food Res. 2007, 51, 732-737. [CrossRef]

15. Jensen, H.D.; Struve, C.; Christensen, S.B.; Krogfelt, K.A. Cranberry juice and combinations of its organic acids are effective against experimental urinary tract infection. Front. Microbiol. 2017, 8, 542. [CrossRef]

16. Jepson, R.G.; Williams, G.; Craig, J.C. Cranberries for preventing urinary tract infections. Cochrane Database Syst. Rev. 2012, 10, CD001321. [CrossRef]

17. Milbury, P.E.; Vita, J.A.; Blumberg, J.B. Anthocyanins are bioavailable in humans following an acute dose of cranberry juice. J. Nutr. 2010, 140, 1099-1104. [CrossRef]

18. Jepson, R.G.; Craig, J.C. A systematic review of the evidence for cranberries and blueberries in UTI prevention. Mol. Nutr. Food Res. 2007, 51, 738-745. [CrossRef]

19. Cassidy, A. Berry anthocyanin intake and cardiovascular health. Mol. Aspects Med. 2018, 61, 76-82. [CrossRef] [PubMed]

20. Timmers, M.A.; Grace, M.H.; Yousef, G.G.; Lila, M.A. Inter- and intra-seasonal changes in anthocyanin accumulation and global metabolite profiling of six blueberry genotypes. J. Food Compost. Anal. 2017, 59, 105-110. [CrossRef]

21. Brito, A.; Areche, C.; Sepúlveda, B.; Kennelly, E.; Simirgiotis, M. Anthocyanin characterization, total phenolic quantification and antioxidant features of some Chilean edible berry extracts. Molecules 2014, 19, 10936-10955. [CrossRef]

22. Wang, S.Y.; Chen, H.; Camp, M.J.; Ehlenfeldt, M.K. Genotype and growing season influence blueberry antioxidant capacity and other quality attributes. Int. J. Food Sci. Technol. 2012, 47, 1540-1549. [CrossRef]

23. Cerezo, A.B.; Cuevas, E.; Winterhalter, P.; Garcia-Parrilla, M.C.; Troncoso, A.M. Isolation, identification, and antioxidant activity of anthocyanin compounds in Camarosa strawberry. Food Chem. 2010, 123, 574-582. [CrossRef]

24. Wu, Y.; Zhou, Q.; Chen, X.-Y.; Li, X.; Wang, Y.; Zhang, J.-L. Comparison and screening of bioactive phenolic compounds in different blueberry cultivars: Evaluation of anti-oxidation and $\alpha$-glucosidase inhibition effect. Food Res. Int. 2017, 100, 312-324. [CrossRef]

25. Prior, R.L.; Cao, G.; Martin, A.; Sofic, E.; McEwen, J.; O’Brien, C.; Lischner, N.; Ehlenfeldt, M.; Kalt, W.; Krewer, G.; et al. Antioxidant capacity as influenced by total phenolic and anthocyanin content, maturity, and variety of Vaccinium species. J. Agric. Food Chem. 1998, 46, 2686-2693. [CrossRef]

26. US Department of Agriculture. USDA Database for the Flavonoid Content of Selected Foods: Release 3.1. US Department of Agriculture, Washington (DC). 2014. Available online: https://data.nal.usda.gov/dataset/ usda-database-flavonoid-content-selected-foods-release-31-may-2014 (accessed on 30 April 2020).

27. Phenol Explorer. Available online: http://phenol-explorer.eu/ (accessed on 28 April 2020).

28. Wu, X.; Beecher, G.R.; Holden, J.M.; Haytowitz, D.B.; Gebhardt, S.E.; Prior, R.L. Concentrations of anthocyanins in common foods in the United States and estimation of normal consumption. J. Agric. Food Chem. 2006, 54, 4069-4075. [CrossRef]

29. Kalt, W.; Cassidy, A.; Howard, L.R.; Krikorian, R.; Stull, A.J.; Tremblay, F.; Zamora-Ros, R. Recent research on the health benefits of blueberries and their anthocyanins. Adv. Nutr. 2019. [CrossRef]

30. Spinardi, A.; Cola, G.; Gardana, C.S.; Mignani, I. Variation of anthocyanin content and profile throughout fruit development and ripening of highbush blueberry cultivars grown at two different altitudes. Front. Plant Sci. 2019, 10, 1319. [CrossRef]

31. Bunea, A.; Rugina, D.; Sconta, Z.; Pop, R.M.; Pintea, A.; Socaciu, C.; Tabaran, F.; Grootaert, C.; Struijs, K.; VanCamp, J. Anthocyanin determination in blueberry extracts from various cultivars and their antiproliferative and apoptotic properties in B16-F10 metastatic murine melanoma cells. Phytochemistry 2013, 95, 436-444. [CrossRef]

32. Pertuzatti, P.B.; Barcia, M.T.; Rebello, L.P.G.; Gómez-Alonso, S.; Duarte, R.M.T.; Duarte, M.C.T.; Godoy, H.T.; Hermosín-Gutiérrez, I. Antimicrobial activity and differentiation of anthocyanin profiles of rabbiteye and highbush blueberries using HPLC-DAD-ESI-MS n and multivariate analysis. J. Funct. Foods 2016, 26, 506-516. [CrossRef] 
33. Prior, R.L.; Lazarus, S.A.; Cao, G.H.; Muccitelli, H.; Hammerstone, J.F. Identification of procyanidins and anthocyanins in blueberries and cranberries (Vaccinium spp.) using high-performance liquid chromatography/mass spectrometry. J. Agric. Food Chem. 2001, 49, 1270-1276. [CrossRef] [PubMed]

34. Silva, S.; Costa, E.M.; Calhau, C.; Morais, R.M.; Pintado, M.M.E. Production of a food grade blueberry extract rich in anthocyanins: Selection of solvents, extraction conditions and purification method. J. Food Meas. Charact. 2017, 11, 1248-1253. [CrossRef]

35. Andreotti, C.; Castagnoli, M.; Maltoni, M.L.; Magnani, S.; Fontanari, M.; Carlini, A.; Marchesini, A.; Pititto, A.; Faedi, W.; Baudino, M. Quality and Phenolic Composition of Blueberries Cultivated in Italy; International Society for Horticultural Science (ISHS): Leuven, Belgium, 2014.

36. Ribera, A.E.; Reyes-Diaz, M.; Alberdi, M.; Zuñiga, G.E.; Mora, M.L. antioxidant compounds in skin and pulp of fruits change among genotypes and maturity stages in highbush blueberry (Vaccinium corymbosum 1.) grown in Southern Chile. J. Soil Sci. Plant Nutr. 2010, 10, 509-536. [CrossRef]

37. Castrejón, A.D.R.; Eichholz, I.; Rohn, S.; Kroh, L.W.; Huyskens-Keil, S. Phenolic profile and antioxidant activity of highbush blueberry (Vaccinium corymbosum L.) during fruit maturation and ripening. Food Chem. 2008, 109, 564-572. [CrossRef]

38. Yousef, G.G.; Brown, A.F.; Funakoshi, Y.; Mbeunkui, F.; Grace, M.H.; Ballington, J.R.; Loraine, A.; Lila, M.A. Efficient quantification of the health-relevant anthocyanin and phenolic acid profiles in commercial cultivars and breeding selections of blueberries (vaccinium spp.). J. Agric. Food Chem. 2013, 61, 4806-4815. [CrossRef]

39. Tan, K.; Lee, W.S.; Gan, H.; Wang, S. Recognising blueberry fruit of different maturity using histogram oriented gradients and colour features in outdoor scenes. Biosys. Eng. 2018, 176, 59-72. [CrossRef]

40. Junta de Andalucía, Consejería de Agricultura, Ganadería, Pesca y Desarrollo Sostenible.Observatorio de Precios y Mercados. Available online: http://www.juntadeandalucia.es/agriculturaypesca/observatorio/ servlet/FrontController?action=RecordContent\&table=11113\&element=2962762\&subsector=19\& (accessed on 29 April 2020).

41. Cardeñosa, V.; Girones-Vilaplana, A.; Muriel, J.L.; Moreno, D.A.; Moreno-Rojas, J.M. Influence of genotype, cultivation system and irrigation regime on antioxidant capacity and selected phenolics of blueberries (Vaccinium corymbosum L.). Food Chem. 2016, 202, 276-283. [CrossRef]

42. Jimenes, I.M.; da Silva, S.R.; Tezotto-Uliana, J.V.; Cantuarias-Avilés, T. Atributos de qualidade em frutos de mirtileiro 'Snowchaser' de baixa exigência em frio cultivados no Brasil. Rev. Bras. Frutic. 2018, 40. [CrossRef]

43. Ogden, A.B.; Van Iersel, M.W. Southern highbush blueberry production in high tunnels: Temperatures, development, yield, and fruit quality during the establishment years. Hortscience 2009, 44, 1850-1856. [CrossRef]

44. Das, Q.; Islam, M.R.; Marcone, M.F.; Warriner, K.; Diarra, M.S. Potential of berry extracts to control foodborne pathogens. Food Control 2016. [CrossRef]

45. Khalifa, H.O.; Kamimoto, M.; Shimamoto, T.; Shimamoto, T. Antimicrobial effects of blueberry, raspberry, and strawberry aqueous extracts and their effects on virulence gene expression in Vibrio cholerae. Phytother. Res. 2015, 29, 1791-1797. [CrossRef] [PubMed]

46. Lacombe, A.; Tadepalli, S.; Hwang, C.A.; Wu, V.C. Phytochemicals in lowbush wild blueberry inactivate Escherichia coli O157:H7 by damaging its cell membrane. Foodborne Pathog. Dis. 2013, 10, 944-950. [CrossRef]

47. Lacombe, A.; Wu, V.C.H.; White, J.; Tadepalli, S.; Andre, E.E. The antimicrobial properties of the lowbush blueberry (Vaccinium angustifolium) fractional components against foodborne pathogens and the conservation of probiotic Lactobacillus rhamnosus. Food Microbiol. 2012, 30, 124-131. [CrossRef] [PubMed]

48. Park, Y.J.; Biswas, R.; Phillips, R.D.; Chen, J. Antibacterial activities of blueberry and muscadine phenolic extracts. J. Food Sci. 2011, 76, M101-M105. [CrossRef] [PubMed]

49. Shen, X.; Sun, X.; Xie, Q.; Liu, H.; Zhao, Y.; Pan, Y.; Hwang, C.-A.; Wu, V.C.H. Antimicrobial effect of blueberry (Vaccinium corymbosum L.) extracts against the growth of Listeria monocytogenes and Salmonella Enteritidis. Food Control 2014, 35, 159-165. [CrossRef]

50. Silva, S.; Costa, E.M.; Mendes, M.; Morais, R.M.; Calhau, C.; Pintado, M.M. Antimicrobial, antiadhesive and antibiofilm activity of an ethanolic, anthocyanin-rich blueberry extract purified by solid phase extraction. J. Appl. Microbiol. 2016, 121, 693-703. [CrossRef]

51. Sun, X.H.; Hao, L.R.; Xie, Q.C.; Lan, W.Q.; Zhao, Y.; Pan, Y.J.; Wu, V.C. Antimicrobial effects and membrane damage mechanism of blueberry (Vaccinium corymbosum L.) extract against Vibrio parahaemolyticus. Food Control 2020, 111. [CrossRef] 
52. Sun, X.H.; Zhou, T.T.; Wei, C.H.; Lan, W.Q.; Zhao, Y.; Pan, Y.J.; Wu, V.C. Antibacterial effect and mechanism of anthocyanin rich Chinese wild blueberry extract on various foodborne pathogens. Food Control 2018, 94, 155-161. [CrossRef]

53. Zhou, T.-T.; Wei, C.-H.; Lan, W.-Q.; Zhao, Y.; Pan, Y.-J.; Sun, X.-H.; Wu, V.C.H. The effect of Chinese wild blueberry fractions on the growth and membrane integrity of various foodborne pathogens. J. Food Sci. 2020. [CrossRef]

54. Zimmer, K.R.; Blum-Silva, C.H.; Souza, A.L.K.; WulffSchuch, M.; Reginatto, F.H.; Pereira, C.M.P.; Macedo, A.J.; Lencina, C.L. The antibiofilm effect of blueberry fruit cultivars against Staphylococcus epidermidis and Pseudomonas aeruginosa. J. Med. Food 2014, 17, 324-331. [CrossRef]

55. Denev, P.; Ciz, M.; Kratchanova, M.; Blazheva, D. Black chokeberry (Aronia melanocarpa) polyphenols reveal different antioxidant, antimicrobial and neutrophil-modulating activities. Food Chem. 2019, 284, 108-117. [CrossRef] [PubMed]

56. Jurikova, T.; Skrovankova, S.; Mlcek, J.; Balla, S.; Snopek, L. Bioactive compounds, antioxidant activity, and biological effects of European ranberry (Vaccinium oxycoccos). Molecules 2019, 24, 24. [CrossRef]

57. Ofek, I.; Goldhar, J.; Zafriri, D.; Lis, H.; Adar, R.; Sharon, N. Anti-Escherichia-coli adhesin activity of cranberry and blueberry juices. N. Engl. J. Med. 1991, 324, 1599. [PubMed]

58. Schmidt, B.M.; Howell, A.B.; McEniry, B.; Knight, C.T.; Seigler, D.; Erdman, J.W., Jr.; Lila, M.A. Effective separation of potent antiproliferation and antiadhesion components from wild blueberry (Vaccinium angustifolium Ait.) fruits. J. Agric. Food Chem. 2004, 52, 6433-6442. [CrossRef] [PubMed]

59. Dorneanu, R.; CIOANCĂ, O.; Chifiriuc, O.; Albu, E.; TUCHILUŞ, C.; Mircea, C.; Salamon, I.; HĂNCIANU, M. Synergic benefits of Aronia melanocarpa anthocyanin-rich extracts and antibiotics used for urinary tract infections. FARMACIA 2017, 65, 778-783.

60. Salaheen, S.; Peng, M.; Joo, J.; Teramoto, H.; Biswas, D. Eradication and sensitization of methicillin resistant Staphylococcus aureus to methicillin with bioactive extracts of berry pomace. Front. Microbiol. 2017, 8, 253. [CrossRef]

61. Nohynek, L.J.; Alakomi, H.L.; Kahkonen, M.P.; Heinonen, M.; Helander, I.M.; Oksman-Caldentey, K.M.; Puupponen-Pimia, R.H. Berry phenolics: Antimicrobial properties and mechanisms of action against severe human pathogens. Nutr. Cancer 2006, 54, 18-32. [CrossRef]

62. Marhuenda, J.; Alemán, M.D.; Gironés-Vilaplana, A.; Pérez, A.; Caravaca, G.; Figueroa, F.; Mulero, J.; Zafrilla, P. Phenolic composition, antioxidant activity, and in vitro availability of four different berries. J. Chem. 2016, 2016. [CrossRef]

63. Hornedo-Ortega, R.; Álvarez-Fernández, M.A.; Cerezo, A.B.; Garcia-Garcia, I.; Troncoso, A.M.; Garcia-Parrilla, M.C. Influence of fermentation process on the anthocyanin composition of wine and vinegar elaborated from strawberry. J. Food Sci. 2017, 82, 364-372. [CrossRef]

64. Giusti, M.M.; Wrolstad, R.E. Characterization and measurement of anthocyanins by UV-visible spectroscopy. Curr. Protoc. Food Anal. Chem. 2001, 1, F1.2.1-F1.2.13. [CrossRef]

65. Ou, B.; Hampsch-Woodill, M.; Prior, R.L. Development and validation of an improved oxygen radical absorbance capacity assay using fluorescein as the fluorescent probe. J. Agric. Food Chem. 2001, 49, 4619-4626. [CrossRef] [PubMed]

66. Holm, A.; Aabenhus, R. Urine sampling techniques in symptomatic primary-care patients: A diagnostic accuracy review. BMC Fam. Pract. 2016, 17, 72. [CrossRef] [PubMed]

67. Abrar, S.; Ain, N.U.; Liaqat, H.; Hussain, S.; Rasheed, F.; Riaz, S. Distribution of bla $\mathrm{CTX}_{-\mathrm{M}}$, bla $\mathrm{TEM}_{\mathrm{T}}$, bla $\mathrm{SHV}_{\mathrm{SH}}$ and bla OXA genes in extended-spectrum-beta-lactamase-producing clinical isolates: A three-year multi-center study from Lahore, Pakistan. Antimicrob Resist. Infect Control. 2019, 8, 80. [CrossRef] [PubMed]

68. Facklam, R.; Elliott, J.A. Identification, classification, and clinical relevance of catalase-negative, Gram-positive Cocci, excluding the Streptococci and Enterococci. Clin. Microbiol. Rev. 1995, 8, 479-495. [CrossRef] [PubMed]

69. Preuss, H.G.; Echard, B.; Enig, M.; Brook, I.; Elliott, T.B. Minimum inhibitory concentrations of herbal essential oils and monolaurin for Gram-positive and Gram-negative bacteria. Mol. Cell. Biochem. 2005, 272, 29-34. [CrossRef] [PubMed]

70. Semeniuc, C.A.; Pop, C.R.; Rotar, A.M. Antibacterial activity and interactions of plant essential oil combinations against Gram-positive and Gram-negative bacteria. J. Food Drug Anal. 2017, 25, 403-408. [CrossRef] [PubMed]

71. Addinsoft. XLSTAT Statistical and Data Analysis Solution; Addinsoft: Long Island, NY, USA, 2020. 
72. Rodriguez-Mateos, A.; Cifuentes-Gomez, T.; Tabatabaee, S.; Lecras, C.; Spencer, J.P. Procyanidin, anthocyanin, and chlorogenic acid contents of highbush and lowbush blueberries. J. Agric. Food Chem. 2012, 60, 5772-5778. [CrossRef]

73. Wang, H.; Guo, X.; Hu, X.; Li, T.; Fu, X.; Liu, R.H. Comparison of phytochemical profiles, antioxidant and cellular antioxidant activities of different varieties of blueberry (Vaccinium spp.). Food Chem. 2017, 217, 773-781. [CrossRef]

74. Kalt, W.; Ryan, D.A.; Duy, J.C.; Prior, R.L.; Ehlenfeldt, M.K.; Vander Kloet, S.P. Interspecific variation in anthocyanins, phenolics, and antioxidant capacity among genotypes of highbush and lowbush blueberries (Vaccinium section cyanococcus spp.). J. Agric. Food Chem. 2001, 49, 4761-4767. [CrossRef]

75. Wang, Y.; Zhu, J.; Meng, X.; Liu, S.; Mu, J.; Ning, C. Comparison of polyphenol, anthocyanin and antioxidant capacity in four varieties of Lonicera caerulea berry extracts. Food Chem. 2016, 197, 522-529. [CrossRef]

76. Cho, M.J.; Howard, L.R.; Prior, R.L.; Clark, J.R. Flavonoid glycosides and antioxidant capacity of various blackberry, blueberry and red grape genotypes determined by high-performance liquid chromatography/mass spectrometry. J. Sci. Food Agric. 2004, 84, 1771-1782. [CrossRef]

77. Huang, H.; Sun, Y.; Lou, S.; Li, H.; Ye, X. In vitro digestion combined with cellular assay to determine the antioxidant activity in Chinese bayberry (Myrica rubra Sieb. et Zucc.) fruits: A comparison with traditional methods. Food Chem. 2014, 146, 363-370. [CrossRef] [PubMed]

78. Borges, G.; Degeneve, A.; Mullen, W.; Crozier, A. Identification of flavonoid and phenolic antioxidants in black currants, blueberries, raspberries, red currants, and cranberries. J. Agric. Food Chem. 2010, 58, 3901-3909. [CrossRef] [PubMed]

79. Gavrilova, V.; Kajdzanoska, M.; Gjamovski, V.; Stefova, M. Separation, characterization and quantification of phenolic compounds in blueberries and red and black currants by HPLC-DAD-ESI-MSn. J. Agric. Food Chem. 2011, 59, 4009-4018. [CrossRef] [PubMed]

80. Wang, S.Y.; Chen, C.-T.; Sciarappa, W.; Wang, C.Y.; Camp, M.J. Fruit quality, antioxidant capacity, and flavonoid content of organically and conventionally grown blueberries. J. Agric. Food Chem. 2008, 56, 5788-5794. [CrossRef] [PubMed]

81. Wu, X.; Prior, R.L. Systematic identification and characterization of anthocyanins by HPLC-ESI-MS/MS in common foods in the United States: Fruits and berries. J. Agric. Food Chem. 2005, 53, 2589-2599. [CrossRef]

82. Veberic, R.; Slatnar, A.; Bizjak, J.; Stampar, F.; Mikulic-Petkovsek, M. Anthocyanin composition of different wild and cultivated berry species. LWT Food Sci. Technol. 2015, 60, 509-517. [CrossRef]

83. Moze, S.; Polak, T.; Gasperlin, L.; Koron, D.; Vanzo, A.; Poklar Ulrih, N.; Abram, V. Phenolics in Slovenian bilberries ( Vaccinium myrtillus L.) and blueberries (Vaccinium corymbosum L.). J. Agric. Food Chem. 2011, 59, 6998-7004. [CrossRef]

84. Kim, S.A.; Kim,H.W.; Rhee, M.S. Cranberry extract with enhanced bactericidal activities against uropathogenic Escherichia coli within one minute of treatment. LWT 2019, 113. [CrossRef]

85. Hayouni, E.A.; Miled, K.; Boubaker, S.; Bellasfar, Z.; Abedrabba, M.; Iwaski, H.; Oku, H.; Matsui, T.; Limam, F.; Hamdi, M. Hydroalcoholic extract based-ointment from Punica granatum L. peels with enhanced in vivo healing potential on dermal wounds. Phytomedicine 2011, 18, 976-984. [CrossRef]

86. Lacombe, A.; Wu, V.C.H. The potential of berries to serve as selective inhibitors of pathogens and promoters of beneficial microorganisms. Food Qual. Saf. 2017, 1, 3-12. [CrossRef]

87. Salaheen, S.; Jaiswal, E.; Joo, J.; Peng, M.; Ho, R.; Oconnor, D.; Adlerz, K.; Aranda-Espinoza, J.H.; Biswas, D. Bioactive extracts from berry byproducts on the pathogenicity of Salmonella Typhimurium. Int. J. Food Microbiol. 2016, 237, 128-135. [CrossRef] [PubMed]

88. Marcon, J.; Schubert, S.; Stief, C.G.; Magistro, G. In vitro efficacy of phytotherapeutics suggested for prevention and therapy of urinary tract infections. Infection 2019, 47, 937-944. [CrossRef] [PubMed]

89. Silva, S.; Costa, E.M.; Pereira, M.F.; Costa, M.R.; Pintado, M.E. Evaluation of the antimicrobial activity of aqueous extracts from dry Vaccinium corymbosum extracts upon food microorganism. Food Control 2013, 34, 645-650. [CrossRef]

90. Santos, T.R.J.; de Aquino Santana, L.C.L. Antimicrobial potential of exotic fruits residues. S. Afr. J. Bot. 2019, 124, 338-344. [CrossRef]

91. Cătunescu, G.M.; Rotar, A.M.; Pop, C.R.; Diaconeasa, Z.; Bunghez, F.; Socaciu, M.-I.; Semeniuc, C.A. Influence of extraction pre-treatments on some phytochemicals and biological activity of Transylvanian cranberries (Vaccinium vitis-idea L.). LWT 2019, 102, 385-392. [CrossRef] 
92. Diaconeasa, Z.; Iuhas, C.I.; Ayvaz, H.; Rugină, D.; Stanilă, A.; Dulf, F.; Bunea, A.; Socaci, S.A.; Socaciu, C.; Pintea, A. Phytochemical characterization of commercial processed blueberry, blackberry, blackcurrant, cranberry, and raspberry and their antioxidant activity. Antioxidants 2019, 8, 540. [CrossRef]

93. Ibrahim, O.M.S. In vivo and in vitro antibacterial activities of cranberry extract against E. coli O157:H7 in urinary tract infected rats. Adv. Anim. Vet. Sci. 2015, 3, 233-244. [CrossRef]

94. Prieto, L.; Esteban, M.; Salinas, J.; Adot, J.M.; Arlandis, S.; Peri, L.; Cozar, J.M. Consensus document of the Spanish Urological Association on the management of uncomplicated recurrent urinary tract infections. Actas Urológicas Españolas Engl. Ed. 2015, 39, 339-348. [CrossRef]

(C) 2020 by the authors. Licensee MDPI, Basel, Switzerland. This article is an open access article distributed under the terms and conditions of the Creative Commons Attribution (CC BY) license (http://creativecommons.org/licenses/by/4.0/). 